\title{
Spatial distribution of pingos in northern Asia
}

\author{
G. Grosse ${ }^{1}$ and B. M. Jones ${ }^{1,2}$ \\ ${ }^{1}$ Geophysical Institute, University of Alaska Fairbanks, USA \\ ${ }^{2}$ US Geological Survey, Alaska Science Center, USA
}

Received: 11 September 2010 - Published in The Cryosphere Discuss.: 27 September 2010

Revised: 16 December 2010 - Accepted: 19 December 2010 - Published: 7 January 2011

\begin{abstract}
Pingos are prominent periglacial landforms in vast regions of the Arctic and Subarctic. They are indicators of modern and past conditions of permafrost, surface geology, hydrology and climate. A first version of a detailed spatial geodatabase of 6059 pingo locations in a $3.5 \times 10^{6} \mathrm{~km}^{2}$ region of northern Asia was assembled from topographic maps. A first order analysis was carried out with respect to permafrost, landscape characteristics, surface geology, hydrology, climate, and elevation datasets using a Geographic Information System (GIS). Pingo heights in the dataset vary between 2 and $37 \mathrm{~m}$, with a mean height of $4.8 \mathrm{~m}$. About $64 \%$ of the pingos occur in continuous permafrost with high ice content and thick sediments; another $19 \%$ in continuous permafrost with moderate ice content and thick sediments. The majority of these pingos are likely hydrostatic pingos, which are typical of those located in drained thermokarst lake basins of northern lowlands with continuous permafrost. About $82 \%$ of the pingos are located in the tundra bioclimatic zone. Most pingos in the dataset are located in regions with mean annual ground temperatures between -3 and $-11^{\circ} \mathrm{C}$ and mean annual air temperatures between -7 and $-18^{\circ} \mathrm{C}$. The dataset confirms that surface geology and hydrology are key factors for pingo formation and occurrence. Based on model predictions for near-future permafrost distribution, about 2073 pingos (34\%) along the southern margins of permafrost will be located in regions with thawing permafrost by 2100 , which ultimately may lead to increased occurrence of pingo collapse. Based on our dataset and previously published estimates of pingo numbers from other regions, we conclude that there are more than 11000 pingos on Earth.
\end{abstract}

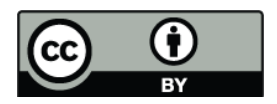

Correspondence to: G. Grosse (ggrosse@gi.alaska.edu)

\section{Introduction}

Periglacial landforms are important climatic and environmental indicators for permafrost-dominated landscapes (French, 1999). Knowledge about the spatial distribution, morphometry, and statistical characteristics of a population of such landforms allows for conclusions on geological, geomorphological, hydrological, and cryological conditions during past and present times. Many detailed studies exist on the spatial distribution and spatial statistics of periglacial landforms such as rock glaciers (Esper-Angillieri, 2009), cryoplanation terraces (Nelson, 1998), solifluction features (Matsuoka, 2001), patterned ground (Walker et al., 2008), palsas (Luoto and Seppälä, 2002), pingos (Mackay, 1962), and thermokarst lakes and basins (Hinkel et al., 2005) in various polar regions. Increasingly, more recent studies make intense use of spatial analysis tools within Geographical Information System (GIS) software, allowing for the study of large digital datasets in combination with various environmental data.

Prominent periglacial features in Polar Regions are perennial frost mounds, including the broad categories of pingos, palsas, and lithalsas. A rich literature exists especially on pingos, which are formed by growth of a massive ice-core in the subsurface and associated long-term frost heave of the terrain surface. Pingos are a clear indicator for the presence of permafrost. Many detailed studies exist on the unique hydrologic, geologic, and permafrost conditions required for their formation (Soloviev, 1952; Bobov, 1960; Mackay, 1962; Holmes et al., 1968; French, 1976; Ferrians, 1988), growth and decay rates (Mackay, 1978a, 1986, 1987, 1998; Yoshikawa, 1991; Yoshikawa and Harada, 1995), and age (Grave, 1956; Craig, 1959; Holmes et al., 1968; Mackay, 1976; Walker et al., 1996; Vasilchuk and Budantseva, 2010). Although the detailed genesis of these perennial frost mounds varies, groundwater migration in unfrozen zones (taliks) within the permafrost plays a key role

Published by Copernicus Publications on behalf of the European Geosciences Union. 
(Mackay, 1978b; review by Gurney, 1998). Subsequent concentrated freezing of water and the formation of a massive ice body are important processes for up-doming of overlying frozen sediments and the terrain surface. Two primary pingo forming processes exist: hydrostatic (formerly "closed system") pingos, and hydraulic (formerly "open system") pingos (Mackay, 1978a, 1979). Hydrostatic pingos are typical of regions underlain by continuous permafrost, whereas hydraulic pingos tend to occur in regions of discontinuous permafrost. Gurney (1998) proposed a third distinguishing pingo-form termed "polygenetic pingos" to categorize all remaining pingo types that do not fit the two main classes. The ice-core growth and related frost heave results in usually conical, dome-like mounds of elliptical to circular planar shape with diameters of up to $600 \mathrm{~m}$ and up to several $10 \mathrm{~m}$ in height (Gurney, 1998) (Fig. 1). Mackay (1998) reports that the highest known pingo is Kadleroshilik Pingo $40 \mathrm{~km}$ southeast of Prudhoe Bay, Alaska, with $54 \mathrm{~m}$ above the surrounding lake plain. Limited examples of the internal structure of a pingo exist and are typically observed in rare cases of pingo collapse due to coastal, fluvial, or thermokarst erosion (Mackay, 1998), derived by mechanical drilling, or measured using geophysical techniques (Yoshikawa et al., 2006; Ross et al., 2005, 2007). Various morphological and structural characteristics of pingos and the dynamics of their formation and collapse are intensely discussed in the literature mentioned above and will therefore not be repeated here. Since the presence of pingos indicates the existence of taliks, permeable layers, and past and/or modern groundwater flow in the subsurface of a permafrost influenced landscape, they are important indicators of hydrogeological conditions in terrestrial permafrost regions (Worsley and Gurney, 1996).

The majority of pingos are reported from pan-Arctic lowlands with continuous and discontinuous permafrost, and to a smaller extent from valleys and plateaus in mountain permafrost regions. In North America, pingo research concentrated on Northwest Canada and Alaska. Initial scientific accounts of pingos in this region are from Leffingwell (1919) and Porsild (1938), followed by intense studies of Mackay (1962, and subsequent years) and many others. In northern Eurasia, detailed scientific research on pingos and their hydrogeology began largely in Siberia in the 1930's (e.g., Tolstikhin, 1932; Andreev, 1936; Soloviev, 1952, 1973; Bobov, 1960; Shumskii and Vtyurin, 1966; Evseev, 1976). Detailed maps of pingo distribution, often based on aerial imagery, exist for many regions of the Arctic (e.g., Holmes et al., 1966, 1968; Mackay, 1966; Galloway and Carter, 1978). Brown and Pewe (1973) summarized the state of knowledge on pingo distribution in North America and provided generalized maps. Mackay (1998) estimated that there are about 5000 or more pingos on Earth, 1350 of which are found on the Tuktoyaktuk Peninsula in NW Canada alone. For Russia, several generalized maps showing provinces of pingo localities exist (e.g., Ershov et al., 1991; Shumskii and Vtyurin, 1966). Numerous local to regional scale maps of periglacial

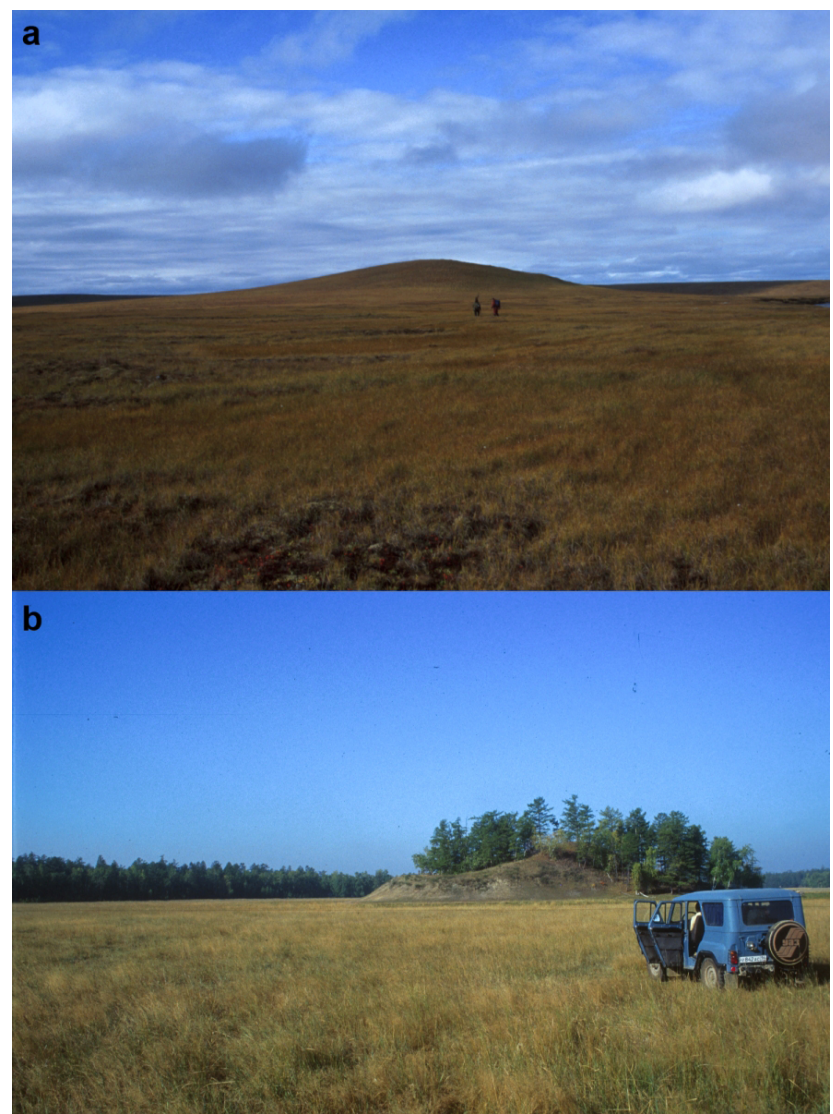

Fig. 1. Ca. $28 \mathrm{~m}$ high closed-system pingo in a drained thermokarst lake basins in the tundra of the Bykovsky Peninsula, North Siberia (top) and ca. $7 \mathrm{~m}$ high partially collapsed closed-system pingo in a dried-up thermokarst lake basin the taiga of central Yakutia (bottom).

geomorphology and permafrost hydrology in Siberia were published in the Russian literature, also showing locations of pingos. Beside the main regions of pingo distribution in NW Canada, Alaska, and Siberia, smaller occurrences of pingos are reported from Greenland (Müller, 1959), Svalbard (e.g., Yoshikawa and Harada, 1995), Scandinavia (Lagerbäck and Rohde, 1985), China (Wang and French, 1995), and Mongolia (Lomborinchen, 2000).

The considerable amount of ground ice stored in pingos renders these frost mounds relatively vulnerable to surface disturbance followed by thaw, erosion, and collapse (Mackay, 1998). Continued climate warming in Arctic regions may cause melting of massive ice bodies in pingos in some regions, resulting in increased collapse of pingos and the formation of remnant lakes (e.g., Mackay, 1988, 1998). Some studies describe local or regional spatial distributions of features linked to pingo collapse and relate their distribution to various past and modern environmental conditions and processes (e.g. Flemal, 1976; Mackay, 1988). Relict pingos are known from various regions that 
formerly experienced periglacial conditions, e.g. central Europe or central North America. Certain circular landscape scars with ramparts in modern, more temperate climate zones are sometimes considered the collapsed product of ice-cored mounds that decayed after permafrost retreated at the end of the last ice age (e.g., Mitchell, 1971; Isarin, 1997; Pissart, 2002). Pingos and their collapsed remnants are thus considered valuable indicators of paleoenvironmental conditions and dynamics, i.e. of climate, permafrost, and hydrology (e.g., Flemal, 1976; Washburn, 1980; Mackay, 1988; Vandenberghe and Pissart, 1993; Isarin, 1997; Huijzer and Vandenberghe, 1998; Jin et al., 2007).

Spatial statistics on a sizeable population of pingos covering a large terrestrial region with a diverse surface geology and hydrology and spanning various climatic and environmental gradients may therefore help in finding correlations between climatic, permafrost, geologic, hydrologic, and morphometric parameters useful for climate and paleoenvironmental modelling (e.g. Harris, 1982; Huijzer and Vandenberghe, 1998), as well as for comparing the distribution of potential submarine and extraterrestrial analogue features. However, although there are many maps showing local and regional pingo distribution and the general occurrence of pingos in the Arctic, detailed GIS-based spatial databases of pingo locations on a large regional or panarctic scale are currently non-existent to our best knowledge.

The primary objective of our study is to introduce an initial GIS dataset on the spatial distribution of pingos for a large region in northern Asia based on digitized features from medium-resolution topographic maps. Though generalized maps of pingo distribution in this large region already exist they do not have the level of detail necessary for analysis of spatial distribution, morphometry, and the relation of pingos to other environmental parameters. In this study, first-order spatial information from this newly assembled pingo dataset is assessed in relation to various other environmental parameters (geology, hydrology, climate, permafrost, glaciation history, topography, geography, and bioclimatic zone). Possible spatial relations are discussed, and some conclusions are drawn on their use as indicators for climatic, environmental and permafrost conditions. We also discuss the impact of near-future diminished permafrost distribution as projected by numerical permafrost models on the North Asian pingo population. Based on the methods and available base data used, the presented dataset should be understood as a conservative (minimum) estimate of pingo numbers in northern Asia and an additional effort towards a detailed global map of pingo distribution.

\section{Study area}

The study area comprises the North Asian lowland regions of North, Northeast, Far East and Central Siberia and adjacent mountain ranges from $60.0^{\circ} \mathrm{N}$ to $76.3^{\circ} \mathrm{N}$ latitude and $60.0^{\circ} \mathrm{E}$ to $168.0^{\circ} \mathrm{W}$ longitude (Fig. 2). The geographic regions covered in this study are the northern part of the West Siberian Lowlands including the Yamal and Gydan peninsulas; Taymyr Peninsula; Putorana Plateau; Khatanga-AnabarOlenek Lowlands; Lena River Delta; Lena River Valley; central Yakutian Lowlands around Yakutsk; Yana-IndigirkaKolyma Lowlands; New Siberian Islands; and the far east Siberian Chukotka region. The total land area included in the study region is $3.48 \times 10^{6} \mathrm{~km}^{2}$. This land area is largely characterized by continuous $\left(3.30 \times 10^{6} \mathrm{~km}^{2} ; 94.7 \%\right)$ and discontinuous $\left(0.15 \times 10^{6} \mathrm{~km}^{2} ; 4.4 \%\right)$ permafrost as well as a very small fraction of other ground $(<0.9 \%)$ (Brown et al., 1998). Climate zones in the study region range from very-cold, arid to moderate-cold, moist climates. Bioclimatic zones, based on Stolbovoi et al. (2002), include polar deserts, tundra, and various forms of taiga. Elevations for the mapped part of the study region range from $0 \mathrm{~m}$ a.s.l. in the Arctic coastal lowlands to $2400 \mathrm{~m}$ a.s.l. in some of the mountain ranges.

\section{Methods}

\subsection{Pingo mapping}

The locations of pingos were manually digitized from 1:200 000 Russian topographic maps (Fig. 2). These medium-scale maps are based on detailed mapping efforts at 1:50000 and 1:100 000, which in turn are derived from aerial photography acquired in the 1970-1980's (Soviet Military Topographic Survey or Voenno-Topograficheskoe Upravlenie General'nogo Shtaba, VTU GSh). Their unique mound shape makes pingos important relief, survey, and viewpoint features especially in otherwise flat lowlands, warranting their inclusion also in medium-scale maps even if their actual size is of insufficient size for the map scale. According to Russian cartographic standards used in these maps, such mounds are indicated either with a specific symbol (red star), or, if diameter and height warrant, by contour lines, both usually accompanied by a Russian map label for pingo (Fig. 3). Labels used in these maps to indicate pingos include the classical Yakutian term bulgunnyakh, the term ledyanoy bugor mostly used in West Siberia, and the more widely used term ledyanoy kholm. These terms are partially based on regional terminology for the same feature and partially based on different hypotheses on their genesis. The term bulgunnyakh, e.g., specifically describes pingos that form during freezing of closed or semi-closed taliks. In a few cases, pingo fields consisting of multiple spatially close pingos were specified in the maps, which were mapped by us as single pingo occurrence because of lacking detailed information on the exact pingo numbers in such an area.

With few exceptions, most of the map sheets cover an area of 2 degrees longitude by $40 \mathrm{~min}$ latitude. The original maps are projected in Gauss-Krueger with Pulkovo 1942 datum. The entire map dataset was available in digital form 


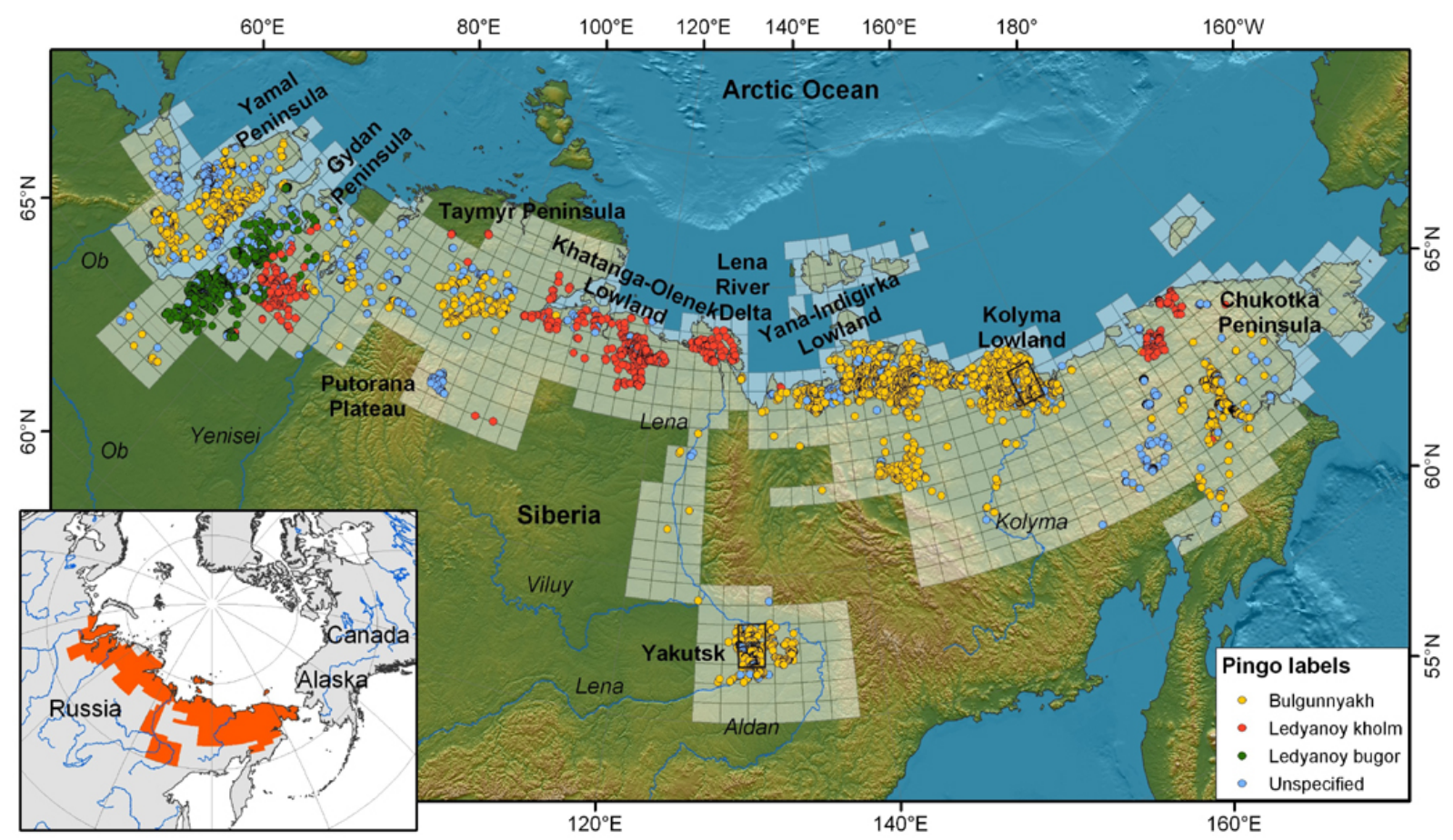

Fig. 2. Location of study region in North Asia (map inset) and distribution of 6059 pingos (large map) digitized from 675 topographic maps 1:200 000 (red area in map inset and light semitransparent frames in large map). Small black frames mark the outlines of subregions shown in Fig. 6 (Yakutsk and Kolyma Lowland).

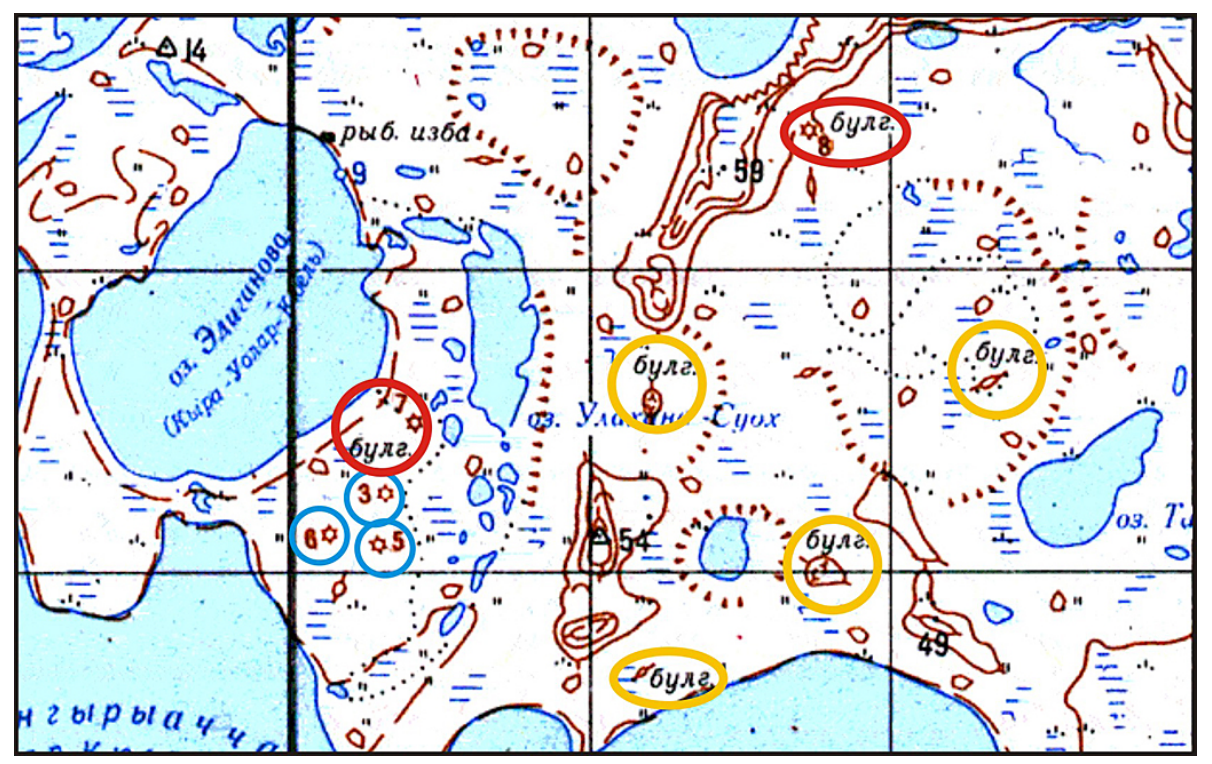

Fig. 3. Subset of topographic map 1:200 000 from the Indigirka lowland with examples of pingos (grid spacing is $4 \mathrm{~km}$ ). Red circles - pingos are marked with red star and the label "bulg." for bulgunnyakh, height given in m; blue circles - pingos are marked with red star but not specifically labelled, height given in m; yellow circles - pingos are marked with contour lines and the label "bulg.". 
Table 1. Comparison of pingo mapping results between 1:250 000 topogaphic maps and selected Terra ASTER late winter imagery.

\begin{tabular}{|c|c|c|c|c|c|c|c|}
\hline Region & Image date & Pingos & & & & & \\
\hline $\begin{array}{l}\text { Aster scene ID } \\
\text { (scene center } \\
\text { coordinates) }\end{array}$ & & $\begin{array}{l}\text { ASTER } \\
\text { scene }\end{array}$ & $\begin{array}{l}\text { Topo } \\
\text { map }\end{array}$ & $\begin{array}{l}\text { Ratio } \\
\text { Aster to } \\
\text { map }\end{array}$ & $\begin{array}{l}\text { In both } \\
\text { datasets }\end{array}$ & $\begin{array}{l}\text { False } \\
\text { positive }^{\mathrm{a}}\end{array}$ & $\begin{array}{l}\text { False } \\
\text { negative }^{b}\end{array}$ \\
\hline \multirow[t]{2}{*}{ Anabar Lowland } & \multirow[t]{2}{*}{12 March 2007} & 58 & 35 & $1.7: 1$ & 28 & 7 & 30 \\
\hline & & AST_L1B & 031220 & 28_20070 & $85245 \_24$ & $\left(72.7412^{\circ} \mathrm{N}\right.$ & $\left.115.7203^{\circ} \mathrm{E}\right)$ \\
\hline \multirow[t]{2}{*}{ Lena Delta } & \multirow[t]{2}{*}{5 March 2007} & 44 & 35 & $1.3: 1$ & 30 & 5 & 14 \\
\hline & & AST_L1B & 303052 & $559 \_2007$ & 061210_4 & $\left(72.7471^{\circ} \mathrm{N}\right.$ & $\left.124.8090^{\circ} \mathrm{E}\right)$ \\
\hline \multirow[t]{2}{*}{ Yana Lowland } & \multirow[t]{2}{*}{6 March 2007} & 248 & 15 & 16.3:1 & 12 & 3 & 236 \\
\hline & & AST_L1B & 030620 & 57_20080 & $03605 \_19$ & $\left(71.2113^{\circ} \mathrm{N}\right.$ & $\left.133.3240^{\circ} \mathrm{E}\right)$ \\
\hline \multirow[t]{2}{*}{ Yana Delta } & \multirow[t]{2}{*}{3 March 2007} & 125 & 40 & $3.2: 1$ & 28 & 12 & 97 \\
\hline & & AST_L1B. & 030320 & $12 \_20070$ & 85745_27 & $\left(71.2769^{\circ} \mathrm{N}\right.$ & $\left.136.6723^{\circ} \mathrm{E}\right)$ \\
\hline \multirow[t]{2}{*}{ Indigirka Lowland } & \multirow{2}{*}{14 March 2007} & 107 & 69 & $1.6: 1$ & 53 & 16 & 54 \\
\hline & & AST_L1B & 303142 & 131_2007 & $190551 \_4$ & $\left(71.7675^{\circ} \mathrm{N}\right.$ & $\left.142.0122^{\circ} \mathrm{E}\right)$ \\
\hline \multirow[t]{2}{*}{ Indigirka Lowland } & \multirow[t]{2}{*}{19 March 2000} & 97 & 53 & $1.8: 1$ & 48 & 6 & 49 \\
\hline & & AST_L1B & 303192 & $005 \_2007$ & 185850_1 & $\left(71.3376^{\circ} \mathrm{N}\right.$ & $\left.146.4542^{\circ} \mathrm{E}\right)$ \\
\hline
\end{tabular}

a False positive are pingos that were identified in the topographic maps but were not found in the ASTER imagery.

${ }^{b}$ False negative are pingos that were identified in the ASTER imagery but were not marked in the topographic maps.

(MicroGlobe LLC) and imported in a desktop GIS. Each map tile was then visually searched for pingos and identified features were marked with a point in a point layer. If available, additional map-derived information was added in an attribute table: pingo height above surrounding terrain; absolute height above mean sea level; and Russian label for the mound. Eventually, the complete point layer was exported and converted to a dataset with geographic latitude-longitude coordinates in datum WGS-84.

\subsection{Accuracy assessment}

Three main error sources exist for pingo locations derived from the maps. First, errors can be inherited from the original mapping efforts based on stereo aerial imagery, including potential mis-interpretation of features as pingos or missing of true pingos by the image interpreters (particularly in forested regions). Second, errors in our dataset could be related to an intentional decreasing of information content for map clarity in the scaling process during map production going from aerial imagery mapping to generation of fine-scale resolution maps and eventually to the medium-resolution maps used in this study. Last, potential location errors are related to georeferencing of the original aerial imagery and the produced maps. We assume a horizontal geo-locational error of up to $250 \mathrm{~m}$ based on individual map quality and georeferencing. Further studies need to be conducted to assess accuracy and completeness of the map-derived pingo locations in the entire study region. Such studies would include field ground truthing, high-resolution satellite image analysis, and incorporation of existing local high-resolution pingo maps.
We performed an initial accuracy assessment that consisted of image analysis of six cloud-free scenes of late winter Advanced Spaceborne Thermal Emission and Reflection Radiometer (ASTER) satellite images onboard Terra from different subregions in northern lowland tundra (Table 1). ASTER imagery from 2000 and 2007 from the TerraLook Collection was acquired from the United States Geological Survey (USGS) Earth Resources Observation and Science (EROS) Center website. The TerraLook ASTER images were produced as simulated natural color images using the green, red and near infrared bands, and have a pixel size of $15 \mathrm{~m}$ and a foot print of about $3600 \mathrm{~km}^{2}$. Late winter optical satellite imagery (February to March) of northern high latitude tundra regions has unique properties that aides mapping of relief features such as pingos. Relatively homogeneous snow cover provides a homogeneous surface reflectance over the entire image scene, while a low sun angle and southern sun position results in pronounced shadows and strong contrasts between sun-facing (south) and sun-opposing (north) slopes. Even low to moderate relief features, such as pingos, are visible in the winter imagery, which resemble shaded relief maps produced from digital elevation models. Pronounced circular to elliptic elevation features, such as pingos, in otherwise relatively flat thermokarst basins or fluvial landscapes with homogeneous reflectance stand out in such imagery by having a very bright sun-facing side and a long shadow on the sun-opposing side (Fig. 4).

We manually mapped pingos in the six ASTER scenes and compared the number of identified pingos with that derived from the topographic maps for the same area (Table 1). We clearly found more pingos in all ASTER scenes than were marked in the 1:200000 scale topographic maps, which is 

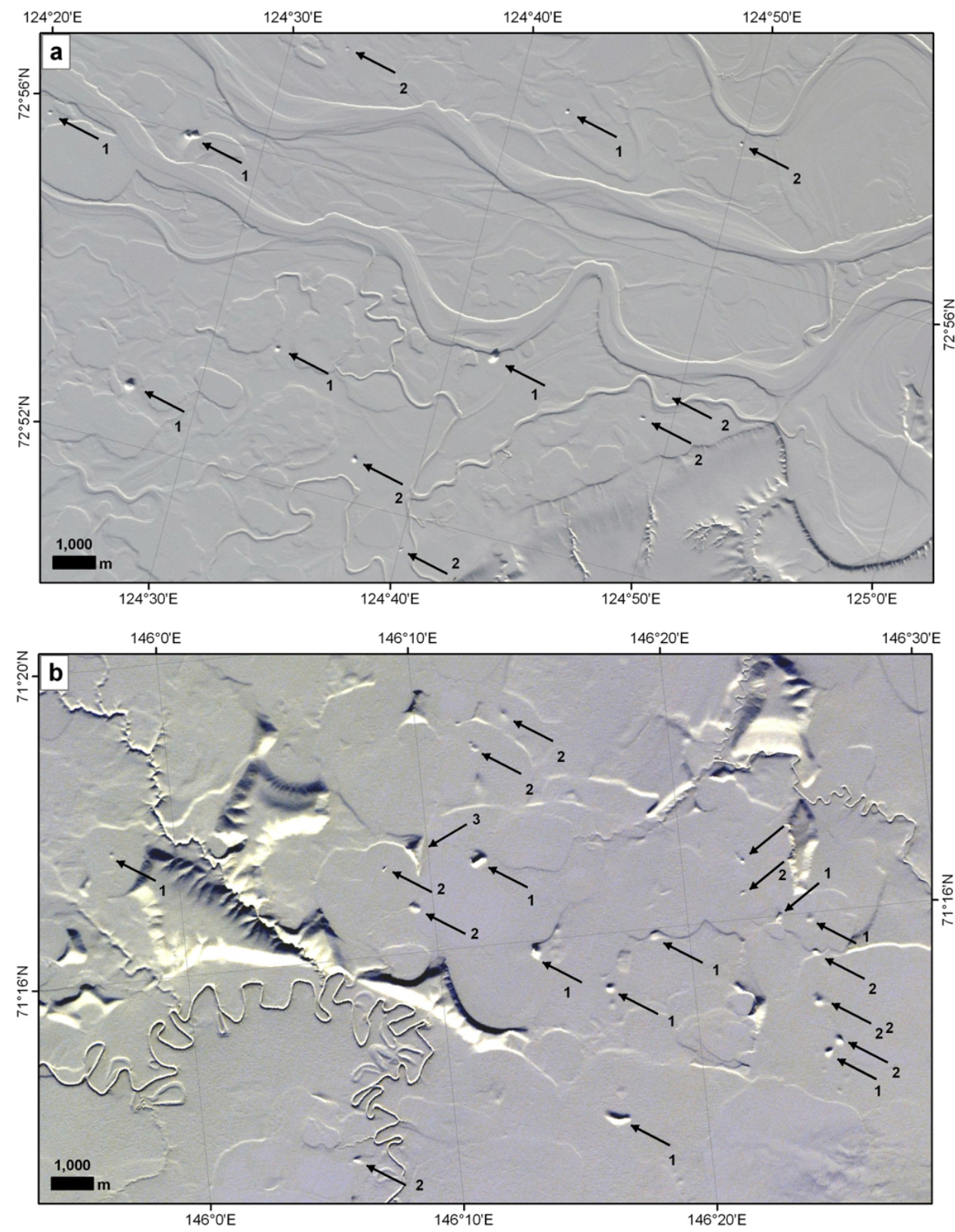

Fig. 4. Mapping of pingos using Terra ASTER late winter imagery for assessment of completeness of pingo locations in 1:200 000 topographic maps. (a) - Fluvial floodplain of the first terrace of the Lena River Delta with numerous pingos (black arrows); (b) - lowland landscape strongly dissected by thermokarst lakes and basins with numerous pingos; note also large Yedoma remnants. Numbers indicate: 1 - pingos identified in both topographic map and ASTER data; 2 - pingos identified only in ASTER data, but not in topographic map; 3 - pingos identified only in topographic map, but not in ASTER data. Note general variation in shape and size of pingos (sun illumination approximately from south).

likely related to a reduction in resolution and the intentional loss of some spatial information in a medium-resolution map. Pingos found in ASTER imagery but not identified in topographic maps are considered false negatives in our accuracy assessment. Furthermore, some pingos marked in the maps could not be identified in our ASTER scenes, which we considered false positives. These could be related to snow drifts smoothing out shallow pingos and thus making them invis- ible to our method, or to the collapse or erosion of some of the pingos over the time period between data collection for maps and the ASTER scene acquisition (20 to 37 years). For all ASTER scenes we found more false negatives than false positives. Assuming all ASTER identified features (Fig. 4) are true pingos, ratios for pingo numbers between ASTER: topo map range from 1.3:1 to 16.3:1 (Table 1), highlighting that our current dataset is an underestimation of pingos and 
Table 2. Various datasets analysed in relation to identified pingos.

\begin{tabular}{|c|c|}
\hline Parameter & Source and characteristics of main parameter \\
\hline Pingo location & Russian topographic maps 1:200 000; point location \\
\hline Pingo height & Russian topographic maps 1:200000 \\
\hline Pingo spatial density & This paper; number of pingos per $100 \mathrm{~km}^{2}$ \\
\hline Elevation above sea level & $\begin{array}{l}\text { GLOBE digital elevation model (Globe Task Team, 1999); } \\
1 \mathrm{~m} \text { vertical and } 1 \mathrm{~km} \text { horizontal resolution }\end{array}$ \\
\hline Limnicity & $\begin{array}{l}\text { Derived from Global Lake and Wetland Database } \\
\text { (Lehner and Döll, 2004) corrected by excluding lagoons and rivers; } \\
\text { scale } 1: 1 \text { to } 1: 3 \mathrm{Mio} \text {; includes lakes } \geq 0.1 \mathrm{~km}^{2} \text {; lake density ranges } \\
\text { from } 0-100 \% \text { with resolution of } 1 \%\end{array}$ \\
\hline Maximum ALT in 2000 and 2100 & $\begin{array}{l}\text { UAF Geophysical Institute Permafrost Model (GIPL 1) output } \\
\text { (Romanovsky et al., 2008; Sazonova and Romanovsky, 2003); } \\
0.5^{\circ} \text { lat/long resolution; ALT have ca. } 1 \mathrm{~cm} \text { vertical resolution }\end{array}$ \\
\hline Past glaciation extent & $\begin{array}{l}\text { Ehlers and Gibbard (2003); Extent of continental ice sheets and } \\
\text { mountain glaciations during the Last Glacial Maximum }\end{array}$ \\
\hline \multicolumn{2}{|c|}{ Land Resources of Russia CD-ROM (Stolbovoy and McCullum, 2002) } \\
\hline MAAT & $\begin{array}{l}\text { New et al. (1999); } 0.5^{\circ} \text { lat/long resolution; } \\
\text { observation period } 1961-1990 \text {; resolution is } 0.1^{\circ} \mathrm{C}\end{array}$ \\
\hline MAP & $\begin{array}{l}\text { New et al. (1999); } 0.5^{\circ} \text { lat/long resolution; } \\
\text { observation period } 1961-1990 \text {; resolution is } 1 \mathrm{~mm}\end{array}$ \\
\hline MAGT & $\begin{array}{l}\text { Kotlyakov and Khromova (2002); scale ca. 1:10 Mio; } \\
\text { zones of } 2{ }^{\circ} \mathrm{C} \text { range are distinguished }\end{array}$ \\
\hline Lithology & Stolbovoi et al. (2002); scale ca. 1:10 Mio; condensed to 9 classes \\
\hline Bioclimatic zone & $\begin{array}{l}\text { Stolbovoi et al. (1998); scale ca. 1:4 Mio; eight vegetation zones, } \\
\text { one non-vegetation zone, and one water class are distinguished }\end{array}$ \\
\hline \multicolumn{2}{|c|}{ International Map of Permafrost and Ground Ice Conditions (Brown et al., 1998) } \\
\hline Permafrost extent & $\begin{array}{l}\text { Brown et al. (1998); scale 1:10 Mio; four distinguished permafrost } \\
\text { classes include: isolated (0-10\%), sporadic }(10-50 \%) \text {, } \\
\text { discontinuous (50-90\%), and continuous }(90-100 \%) \text { permafrost }\end{array}$ \\
\hline Ground ice content & $\begin{array}{l}\text { Brown et al. (1998); scale 1:10 Mio; Ground ice contents } \\
\text { by volume are distinguished as low }(0-10 \%) \text {, moderate }(10-20 \%) \\
\text { and high ( }>20 \% \text { in lowlands; }>10 \% \text { in mountains) }\end{array}$ \\
\hline Sediment thickness & $\begin{array}{l}\text { Brown et al. (1998); scale 1:10 Mio; Sediment cover thickness is } \\
\text { distinguished as low }(<5-10 \mathrm{~m}) \text { and high }(>5-10 \mathrm{~m})\end{array}$ \\
\hline
\end{tabular}

should be viewed as a first step towards a complete database of pingo locations that would benefit from updating with more intense satellite image mapping.

\subsection{Spatial data analysis}

For each pingo location, additional parameters were derived from ancillary datasets and added to the attribute table for each pingo using zonal statistics tools and spatial join functions in $\operatorname{ArcGIS}^{\mathrm{TM}}$. We restricted our analysis to datasets that covered the entire study region. The datasets used include the Land Resources of Russia CD-ROM (Stolbovoi and McCallum, 2002), the International Map of Permafrost and Ground Ice Conditions (Brown et al., 1998), the Global Lake and Wetland Database (Lehner and Döll, 2004), the GLOBE $1 \mathrm{~km}$ resolution global digital elevation model, and outputs of the University of Alaska Fairbanks (UAF) Geophysical Institute Permafrost Model (GIPL 1) projecting the spatial distribution of permafrost degradation by 2100 (Romanovsky et al., 2008). The parameters in these datasets included permafrost cover, ground ice content, sediment thickness, mean annual ground temperature (MAGT), mean annual air temperature (MAAT), mean annual precipitation (MAP), bioclimatic zone, surface geology, lake density, elevation above sea level, and maximum annual active layer thickness (ALT) in 2000 and by end of this century (see Table 2 for details on datasets and their source). For most of the datasets the original, unaltered data was used. Exceptions are the surface lithology and the lake density datasets. For the lithology dataset (Stolbovoi et al., 2002) we applied a merge of genetically similar classes to reduce the overall number of 
Table 3. Map labels of 6059 pingos identified in topographic maps 1:200000.

\begin{tabular}{lr}
\hline Map label & Count \\
\hline Bulgunnyakh & 3513 \\
Ledyanoy kholm & 721 \\
Ledyanoy bugor & 699 \\
Not specified & 1126 \\
\hline
\end{tabular}

classes. For the lake density parameter, which is based on the Global Lake and Wetland Database (GLWD) (Lehner and Döll, 2004), we (1) applied manual corrections to the GLWD by selecting lakes only, (2) removed lagoons and streams misclassified as lakes, and (3) generated a lake area density map for all lakes $>10$ ha with $5 \mathrm{~km}$ grid cell resolution using ArcGIS. Basic geographic distribution of pingos as well as pingo distribution in relation to these thematic datasets were plotted in map and histogram form and subsequently analyzed. Some regional characteristics of the identified patterns are discussed. Spatial point density of pingo locations was determined using a $10 \times 10 \mathrm{~km}$ search kernel $\left(100 \mathrm{~km}^{2}\right)$ for a $5 \mathrm{~km}$ grid cell raster (for reporting in text) as well as a $20 \times 20 \mathrm{~km}$ search kernel $\left(400 \mathrm{~km}^{2}\right)$ for a $5 \mathrm{~km}$ grid cell raster (for enhanced clarity in maps).

\section{Results}

A total of 675 map sheets covering an area of $4.00 \times 10^{6} \mathrm{~km}^{2}$ (87\% of it terrestrial) in Northwest, North, Northeast, and Central Siberia were analyzed (Fig. 2). The mapped area covers most of the Siberian lowlands with continuous permafrost. A total of 6059 mounds were identified in 296 map sheets (Fig. 2). The majority were labelled as bulgunnyakh (Table 3). Pingos labelled with ledyanoy bugor are found only in West Siberia, while those labelled with ledyanoy kholm are found broadly across the region (Fig. 2). 1126 mounds were not labelled specifically as pingos in the topographic maps; however, based on map signatures, topographic location, and proximity with other clearly identified pingos occurrences, these were interpreted as pingos and included in this analysis (see also Fig. 3). The number of pingos in the mapped region can be considered a conservative minimum value due to the degree of generalization likely in the 1:200000 scale maps and our comparison with ASTER mapping results proving that numerous pingos are missing in the maps. Pingo counts per map sheet ranged from 0 to a maximum of 231 .

\subsection{Geographic distribution}

Pingos in the study region occur between $61.4^{\circ}-74.7^{\circ}$ northern latitude. However, a clustering is observed for the northern latitudes between $69^{\circ}$ and $72^{\circ}$, where 2990 pingos or $49 \%$ of the mapped population occur (Fig. 5). Pingo num- bers decrease in the lower latitudes, with an exception being the dense pingo occurrence of the central Yakutian region. Several important pingo provinces were identified: about 1620 pingos were mapped on the Yamal and Gydan peninsulas in West Siberia (66.9-86.2 $2^{\circ} \mathrm{E}$ longitude), 260 pingos in the lowlands south of the Taymyr Peninsula $\left(87.2-108.9^{\circ} \mathrm{E}\right), 360$ pingos in the Khatanga-AnabarOlenek lowlands $\left(109.2-120.7^{\circ} \mathrm{E}\right), 85$ pingos in the Lena River Delta $\left(123.5-129.4^{\circ} \mathrm{E}\right), 600$ pingos in central Yakutia $\left(126.0-133.6^{\circ} \mathrm{E}\right), 1500$ pingos in the Yana-Indigirka lowlands $\left(132.4-154.0^{\circ} \mathrm{E}\right), 700$ in the Kolyma Lowlands $\left(150.7-162.5^{\circ} \mathrm{E}\right)$, and 735 pingos in Chukotka $\left(159.5^{\circ} \mathrm{E}-\right.$ $\left.174.3^{\circ} \mathrm{W}\right)$. Figure 6 shows subsets of the pingo distribution north of Yakutsk and in the northern portion of the Kolyma Lowlands. Clearly, some patterns of distribution emerge on this level which are very likely related to local permafrost conditions, hydrology and lithology (see Sects. 4.5 and 4.6).

Several geographic regions have a high density of pingos (Fig. 5). Highest densities occur in the central Yakutian Lowland near Yakutsk with up to 28 pingos per $100 \mathrm{~km}^{2}$ and in the Anadyr River Valley with also up to 28 pingos per $100 \mathrm{~km}^{2}$ (Table 4). A very high density of up to 26 pingos per $100 \mathrm{~km}^{2}$ was also detected for some mountain valleys in Chukotka. For most of the northern lowlands moderate point densities of up to $6-14$ pingos per $100 \mathrm{~km}^{2}$ were identified. Highest pingo point densities in northern lowland plains were encountered on the Gydan Peninsula with 21 pingos per $100 \mathrm{~km}^{2}$ (Table 4). Higher local densities can be expected if focusing on particular landscape elements favourable for pingo formation in such a high density region.

Elevation data clearly indicates that a large number of mapped pingos $(4166 ; 68.8 \%)$ occur in lowland plains dominated by thermokarst lakes and basins below $50 \mathrm{~m}$ a.s.l., mainly found along the Arctic Ocean coasts (Fig. 7). Notable exception are the pingos in the central Yakutian lowland around Yakutsk (600 pingos; mean elevation $160 \pm$ $38 \mathrm{~m}$ a.s.1., $1 \sigma$ ) and smaller populations of pingos in higher densities identified in mountainous regions of Chukotka (123 pingos; mean elevation $633 \pm 112 \mathrm{ma.s.1.,} 1 \sigma$ ) and the Putorana Plateau (49 pingos; mean elevation $699 \pm$ 109 ma.s.1., $1 \sigma)$. Pingos in these mountainous areas are likely hydraulic pingos located in river valleys. Many pingos were found in river estuary and delta regions $(\mathrm{Ob}$, Yenissey, Khatanga, and Anabar estuaries; Lena, Yana, Indigirka, and Kolyma deltas) and as well as large river valleys (Khatanga, Anabar, Lena, Indigirka, Kolyma, and Anadyr rivers). Finally, the majority of pingos in the study region are located in the tundra zone $(4938 ; 81.5 \%)$. Lower numbers are located in the pre-tundra/northern taiga zone $(452 ; 7.4 \%)$ and the middle taiga zone $(670 ; 11.1 \%)$. 


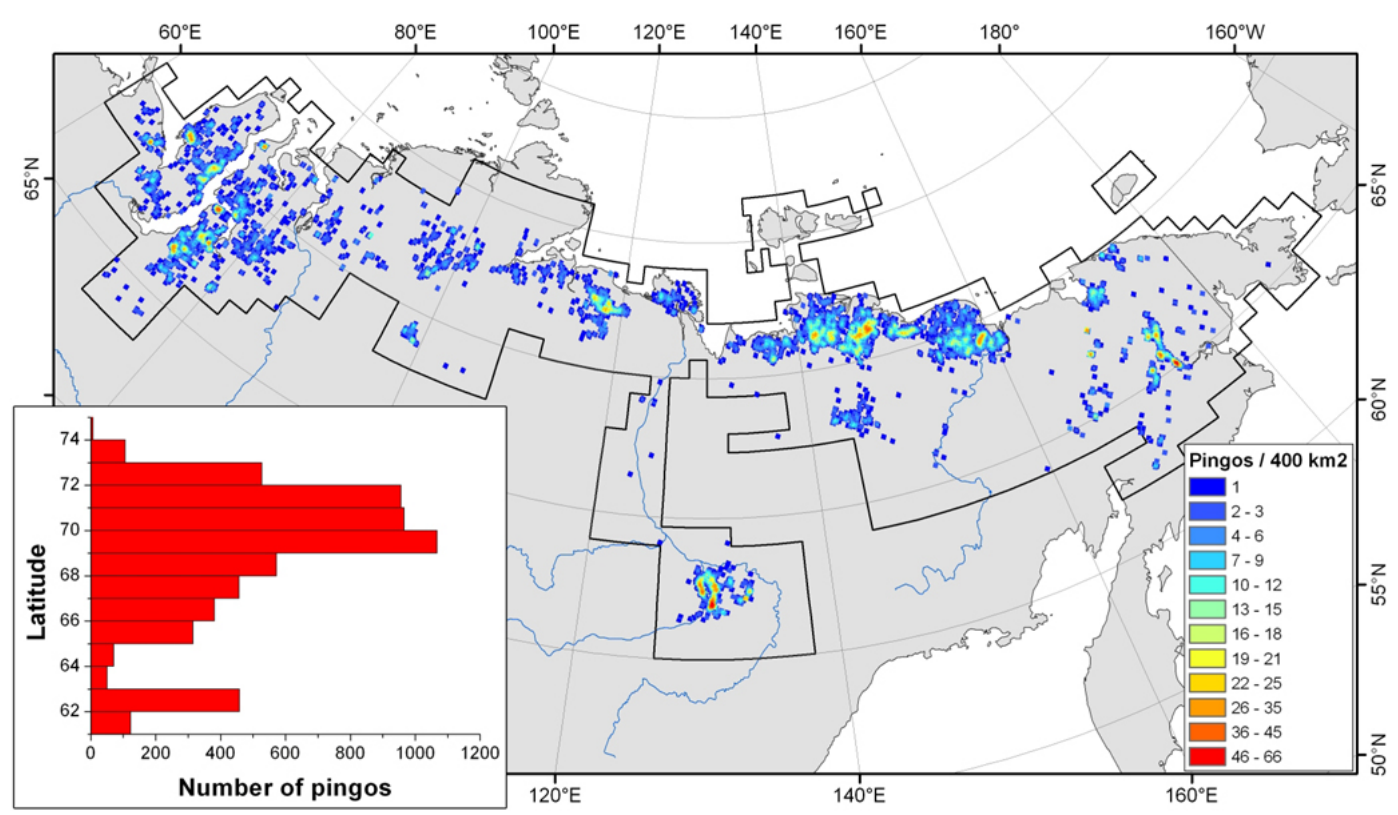

Fig. 5. Spatial point density of pingo locations using a $20 \times 20 \mathrm{~km}$ search window $\left(400 \mathrm{~km}^{2}\right)$ and $5 \mathrm{~km}$ grid cell size. Histogram shows pingo distribution by geographical latitude. Black outline in this and subsequent figures indicates the study area boundary.
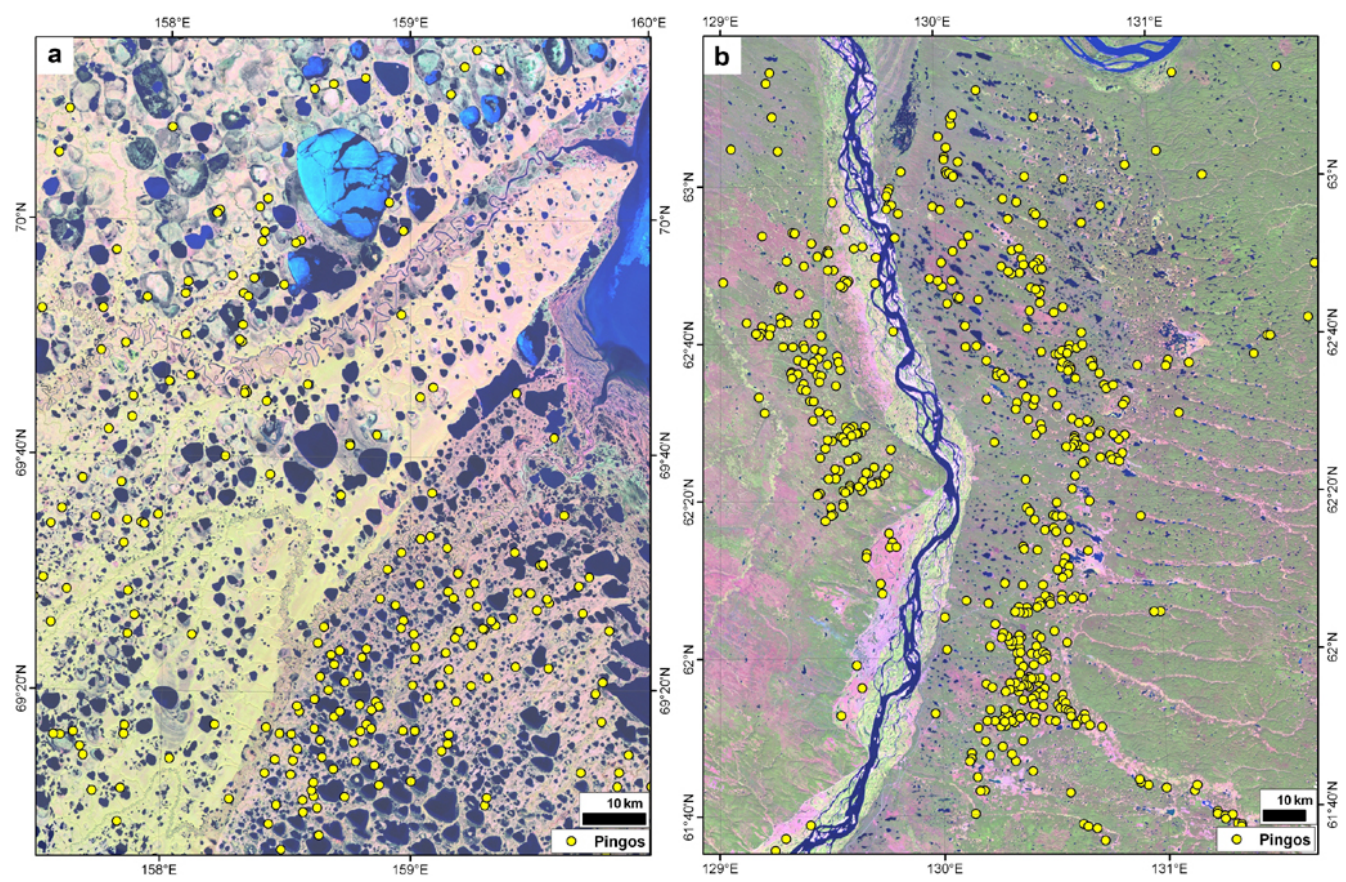

Fig. 6. Local subsets of the pingo distribution in the Kolyma Lowland region (a) and the region north of Yakutsk, central Siberia (b). The distribution of pingos in both subregions seems clearly related to lithology, hydrology, and local permafrost conditions. In (a), pingo distribution is dense and possibly aligend with abandoned paleochannels of the Kolyma River in the Khalertchinskaya Tundra (lower right corner of image), whereas pingo distribution is loose and widespread in the region dominated by Yedoma and large drained lake basins (left and upper left corner). In (b), pingos are clearly aligned with fluvial terraces of the paleo-Lena River east and west of the modern Lena River. Also, there is a clustering of pingos at locations where elongated thermokarst (alas) valleys enter the paleo-Lena terraces from the east. For location of the subsets see Fig. 2. In both subsets the background image is a false color composite from Landsat-ETM+ with RGB bands 5-4-3 from the mid-summer season (data provided by USGS EROS Data Center). 
Table 4. Spatial pingo densities reported from various regions. Depending on study area size and sometimes focus on particular landscape units densities are reported as pingos per $\mathrm{km}^{2}$ (detailed assessment of small areas or landscape units) or pingos per $100 \mathrm{~km}^{2}$ (averaging over large regions).

\begin{tabular}{lll}
\hline Region & Reported density & Source \\
\hline Alaska & & \\
Interior Alaska & $<1 / \mathrm{km}^{2}$ & Holmes et al. (1968) \\
Alaska coastal plain (Beechey Point) & & Walker et al. (1985) \\
$\quad$ Flat thaw lake plains & $0.096 / \mathrm{km}^{2}$ & \\
$\quad$ Gently rolling thaw lake plains & $0.286 / \mathrm{km}^{2}$ & \\
Floodplains & $0.012 / \mathrm{km}^{2}$ & \\
Hills & $0.027 / \mathrm{km}^{2}$ & \\
\hline Siberia & & This study \\
Yamal Peninsula & $<13 / 100 \mathrm{~km}^{2}$ & \\
Gydan Peninsula & $<21 / 100 \mathrm{~km}^{2}$ & \\
Taymyr Lowland & $<12 / 100 \mathrm{~km}^{2}$ & \\
Khatanga-Anabar Lowland & $<13 / 100 \mathrm{~km}^{2}$ & \\
Lena River Delta & $<6 / 100 \mathrm{~km}^{2}$ & \\
Central Yakutian Lowland (Fig. 6b) & $<28 / 100 \mathrm{~km}^{2}$ & \\
Yana River Delta & $<8 / 100 \mathrm{~km}^{2}$ & \\
Indigirka Lowland & $<14 / 100 \mathrm{~km}^{2}$ & \\
Kolyma Lowland (Fig. 6a) & $<12 / 100 \mathrm{~km}^{2}$ & \\
Anadyr River Valley & $<28 / 100 \mathrm{~km}^{2}$ & \\
\hline NW Canada & & \\
Yukon region & $<1 / \mathrm{km}^{2}$ & Worsley and Gurney (1996) \\
Mackenzie region & $<8 / \mathrm{km}^{2}$ & Stager (1956) \\
\hline Greenland & $<11 / \mathrm{km}^{2}$ & \\
Traill Island & & \\
\hline
\end{tabular}

\subsection{Pingo height}

Heights above surrounding terrain were provided in the analyzed topographic maps for 3109 pingos (51.3\% of entire dataset) and ranged from $2 \mathrm{~m}$ to $37 \mathrm{~m}$ with a mean of $4.8 \pm 2.8 \mathrm{~m}(1 \sigma)$ (Fig. 8). A vast majority of the pingos range in height from 2-8 $\mathrm{m}$ (2873 pingos, or $92 \%$ of pingos with height data). Only 236 pingos are higher than $8 \mathrm{~m}$ in this limited heigt dataset ( $8 \%$ of pingos with height data). The 2 highest pingos in the dataset, $36 \mathrm{~m}$ and $37 \mathrm{~m}$, were both found in the lowlands south of Pevek, Chukotka. The pingo on the Bykovsky Peninsula shown in Fig. 1 is $28 \mathrm{~m}$ high and the 3rd highest in this dataset. Such tall pingos occur only in the northern regions of the study area. Beyond this notion, no specific trend in pingo height was observed over this large region except that taller pingos tend to occur in lowlands as compared to higher elevations. Frequently reported pingo heights in Siberia of up to $50 \mathrm{~m}$ could not be confirmed with the present dataset. However, since only for half of the pingos in the dataset direct height values were provided in the maps and the ASTER imagery indicated that numerous pingos remain un-mapped and thus are absent from our mapderived dataset, we cannot rule out the presence of some very large pingos in the study region.

\subsection{Distribution in relation to permafrost parameters}

Based on Brown et al. (1998), the study area is dominated by continuous $(94.7 \%)$ and discontinuous $(4.4 \%)$ permafrost (Fig. 9). The large majority of pingos are located in the continuous permafrost zone $(5948 ; 98.2 \%)$ and only a very small number were found in discontinuous permafrost (111; $1.8 \%$ ) (Fig. 9). Since no isolated and sporadic permafrost regions were included in the dataset compilation and analysis yet, the presence of pingos in these regions remains unclear. Most pingos are found in continuous permafrost regions with large sediment thickness and high ground ice content (Chf; 3897; 64.3\%) or moderate ground ice content (Cmf; 1126; 18.6\%). Pingos in these permafrost types are concentrated in the North Yakutian lowlands and Northeast Siberia, as well as to some extent in Central Yakutia and Northwest Siberia. The remaining pingos $(1036 ; 17.1 \%)$ are spread over other permafrost types with lower ice contents, lower sediment thickness, or discontinuity in permafrost extent. Pingos in regions with lower ground ice contents are also found in Central Yakutia (old Lena river terraces), the valleys south of the Taymyr Peninsula (glacio-fluvial terraces), in Chukotka (mountain valleys), and in Northwest Siberia (glacio-fluvial deposits) (Fig. 9). Some localized 


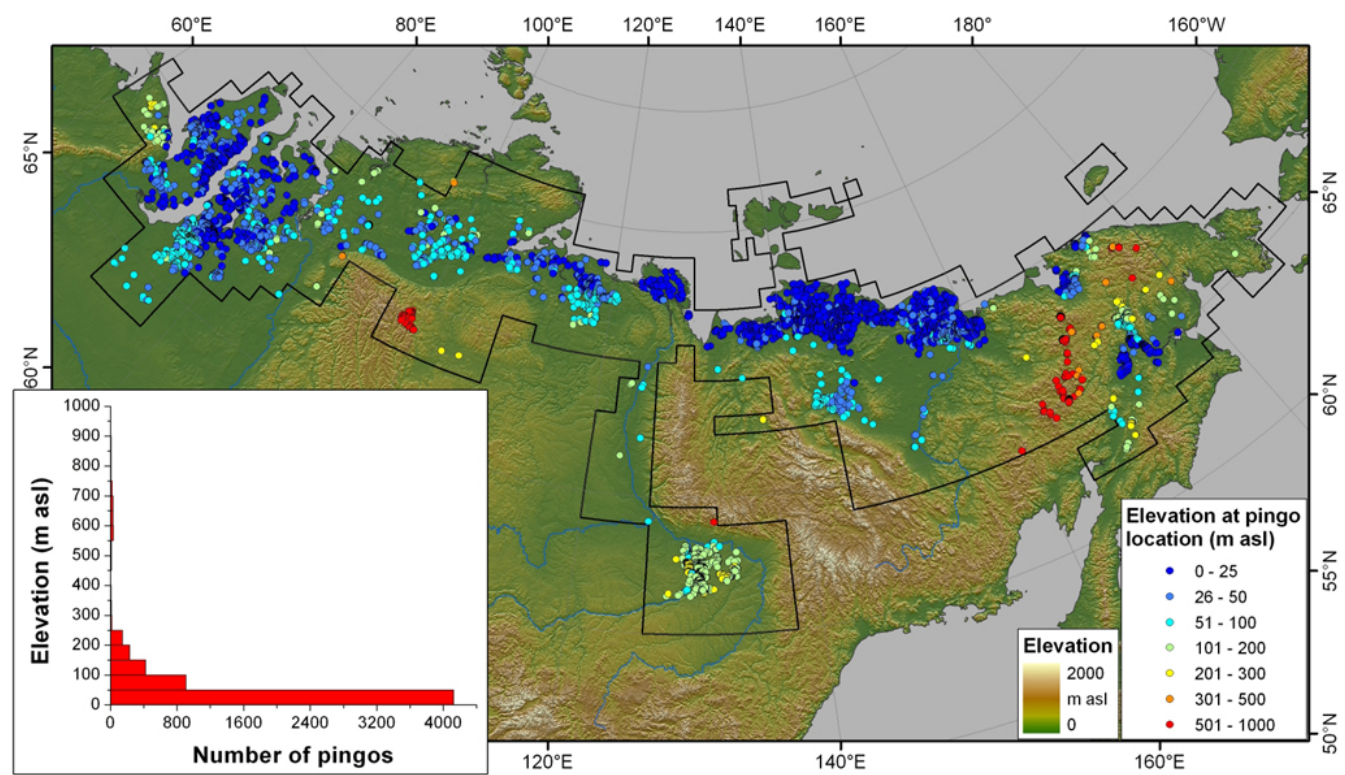

Fig. 7. Elevation of pingo locations above sea level derived from GLOBE global $1 \mathrm{~km}$ DEM (Globe Task Team, 1999). Though the vast majority of pingos occurs in lowlands below $50 \mathrm{~m}$, some pingos occur in up to $1000 \mathrm{~m}$ elevation in some mountain valleys.

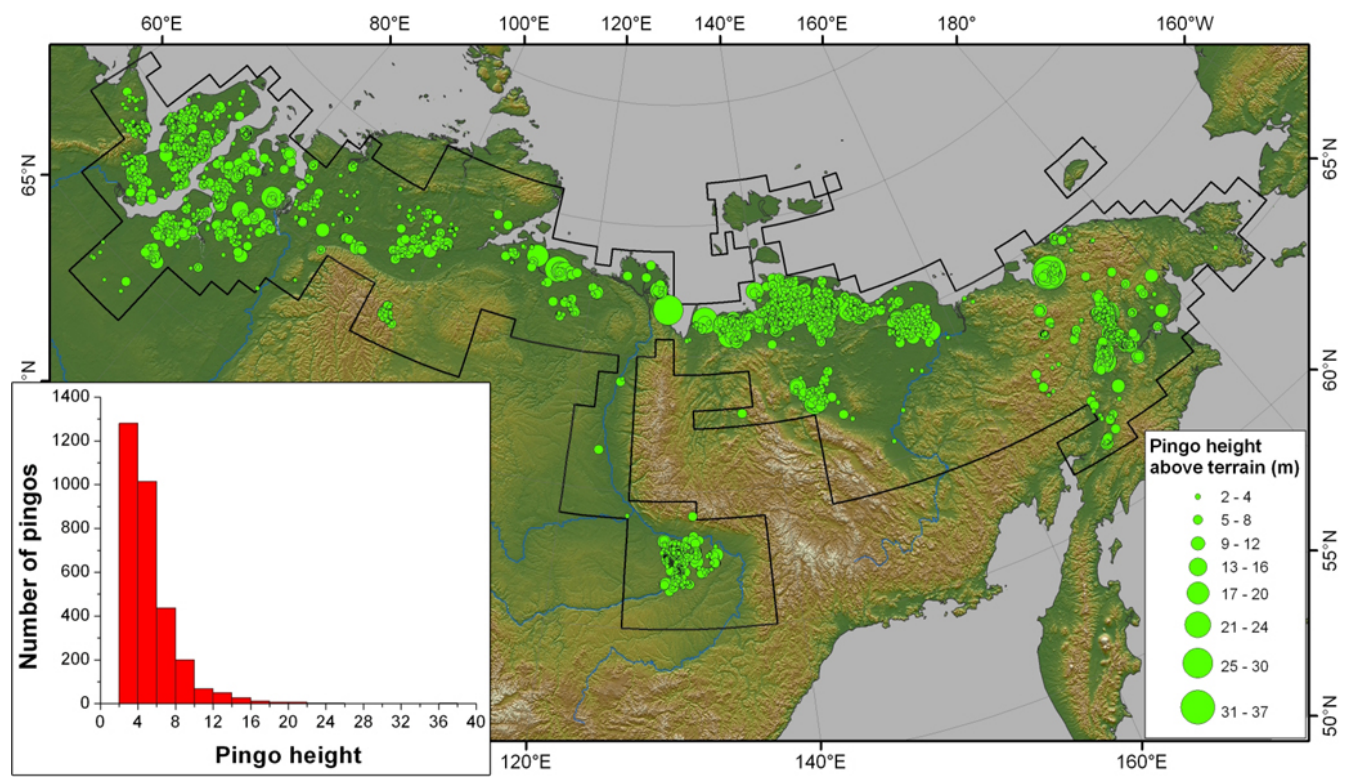

Fig. 8. Height above surrounding terrain for 3109 pingos (51.3\% of dataset) as indicated in topographic maps.

pingo occurrences are confined to regions with low sediment cover, namely in mountain valleys of Chukotka and the Putorana Plateau.

The distribution of pingos in relation to modern mean annual ground temperature (MAGT) reveals an interesting pattern (Fig. 10). Most pingos are confined to permafrost areas with MAGT between -3 and $-11{ }^{\circ} \mathrm{C}(5581 ; 92.1 \%)$. The ground temperature range most populated with pingos is the range from -9 to $-11^{\circ} \mathrm{C}(1931 ; 31.9 \%)$. With higher
MAGT in the range -3 to $-9{ }^{\circ} \mathrm{C}$ there is a gradual decrease in pingo numbers. There is a sharp decline in pingo numbers for MAGT above $-3{ }^{\circ} \mathrm{C}$ and below $-11^{\circ} \mathrm{C}$, most likely due to the limited area in the study region with MAGT below $-11^{\circ} \mathrm{C}$. Small populations of pingos in permafrost warmer than $-3{ }^{\circ} \mathrm{C}$ are found in the southern part of the NW Siberian Lowlands and in the Lena River Valley. 


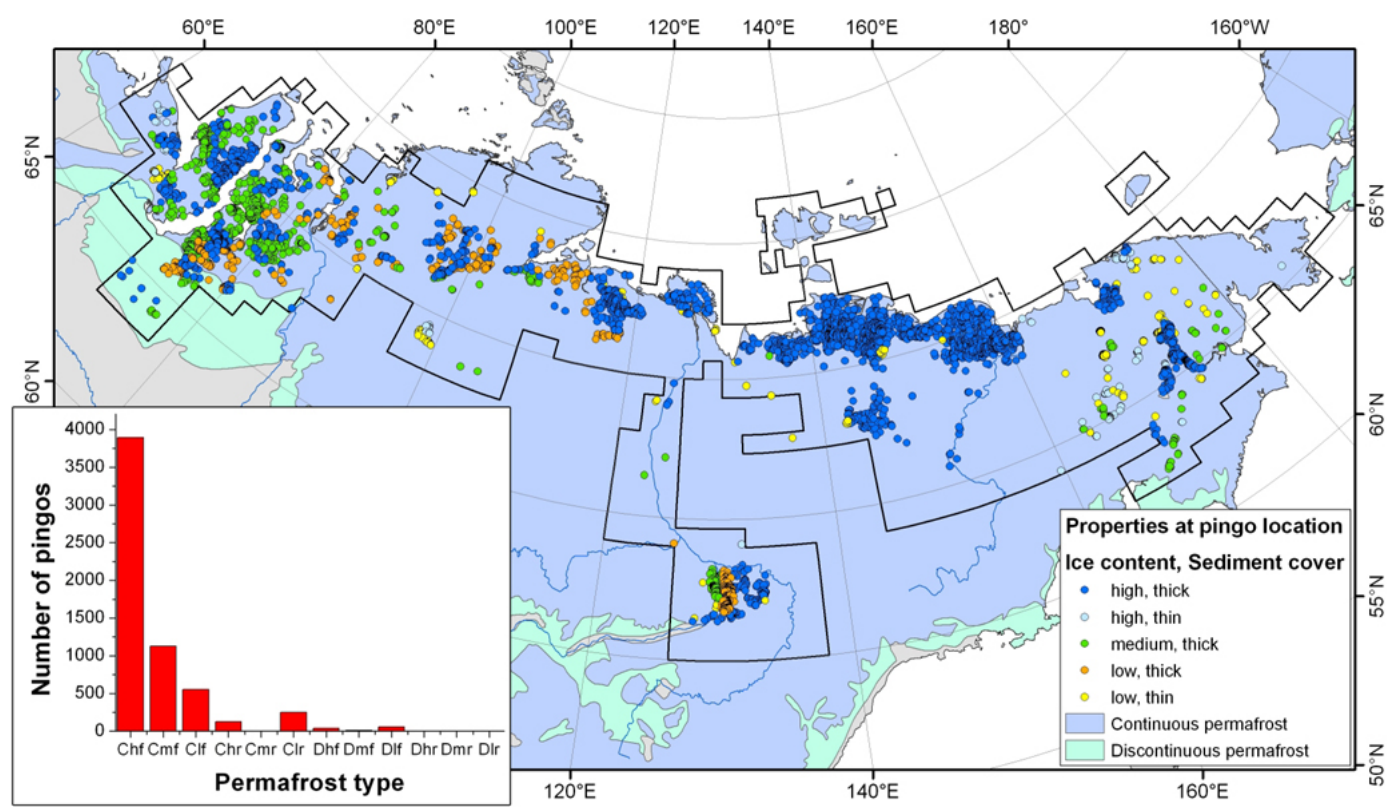

Fig. 9. Pingo distribution by permafrost type, ground ice content, and sediment thickness (based on Brown et al., 1998). (Permafrost type: C - continuous, D - discontinuous; Ground ice content: $\mathrm{h}$ - high, $\mathrm{m}$ - moderate, 1 - low; Sediment thickness: $\mathrm{f}$ - high, $\mathrm{r}$ - low).

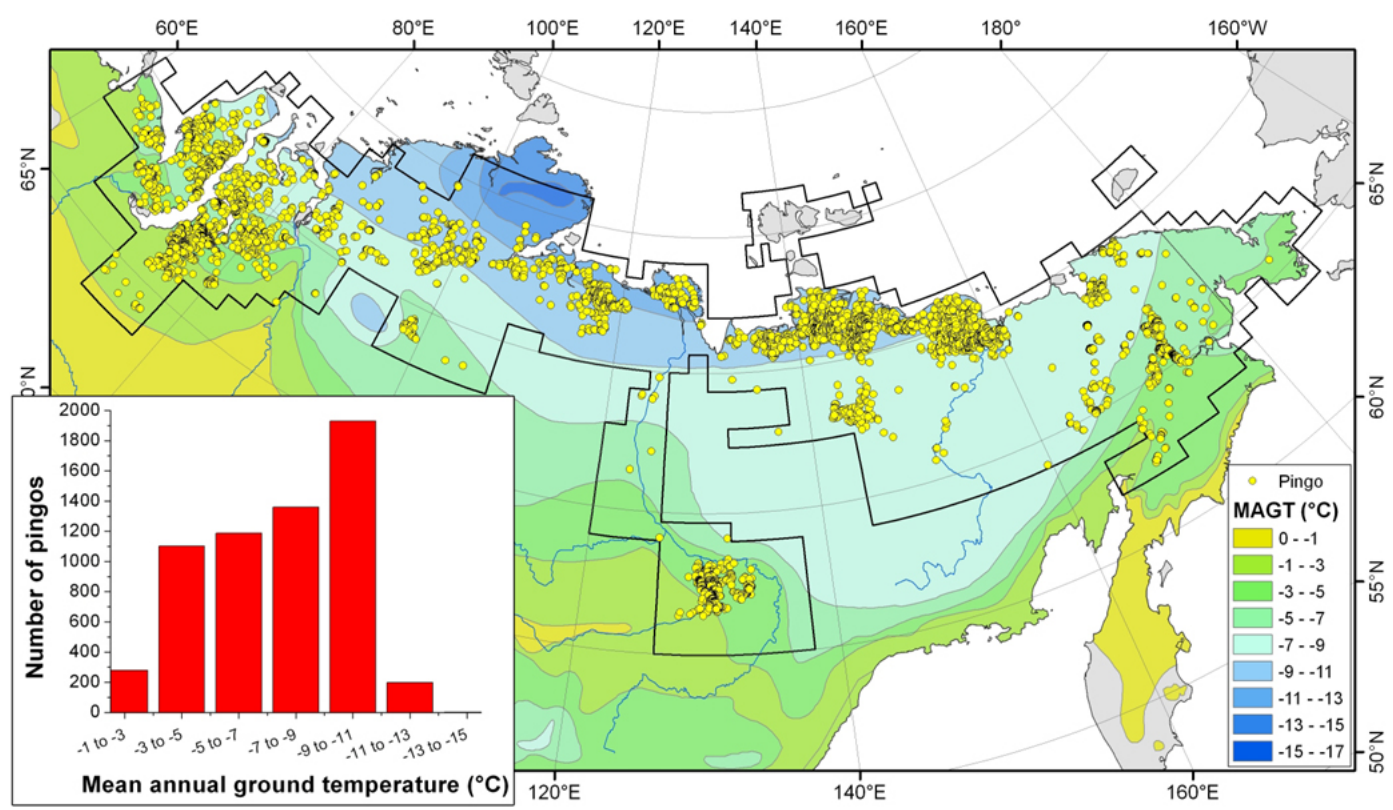

Fig. 10. Pingo distribution by mean annual ground temperature (MAGT) (based on Kotlyakov and Khromova, 2002).

\subsection{Distribution in relation to climate parameters}

The histogram of pingo distribution by MAAT shows a primary distribution of pingos in the study region between -7 and $-18^{\circ} \mathrm{C}(5943 ; 98.1 \%)$ (Fig. 11). There are nearly no pingos in regions with a lower MAAT, which partially might be caused by the lack of land areas suitable for pingo growth in higher latitudes. The pingo-rich regions around Yakutsk as well as in the coastal lowlands of North and Northeast Siberia are dominated by low to very low $\left(-10^{\circ} \mathrm{C}\right.$ to $\left.-18^{\circ} \mathrm{C}\right)$ mean annual air temperatures (MAAT) (Fig. 11). Pingo regions with relatively high MAAT above $-10^{\circ} \mathrm{C}$ are found on the Yamal and Gydan Peninsulas, and in the Pacific part of Chukotka. Pingo numbers also decrease sharply for MAAT above $-7^{\circ} \mathrm{C}(110 ; 1.8 \%)$. Nearly all of these pingos with high MAAT occur in the southern part of the Northwest 


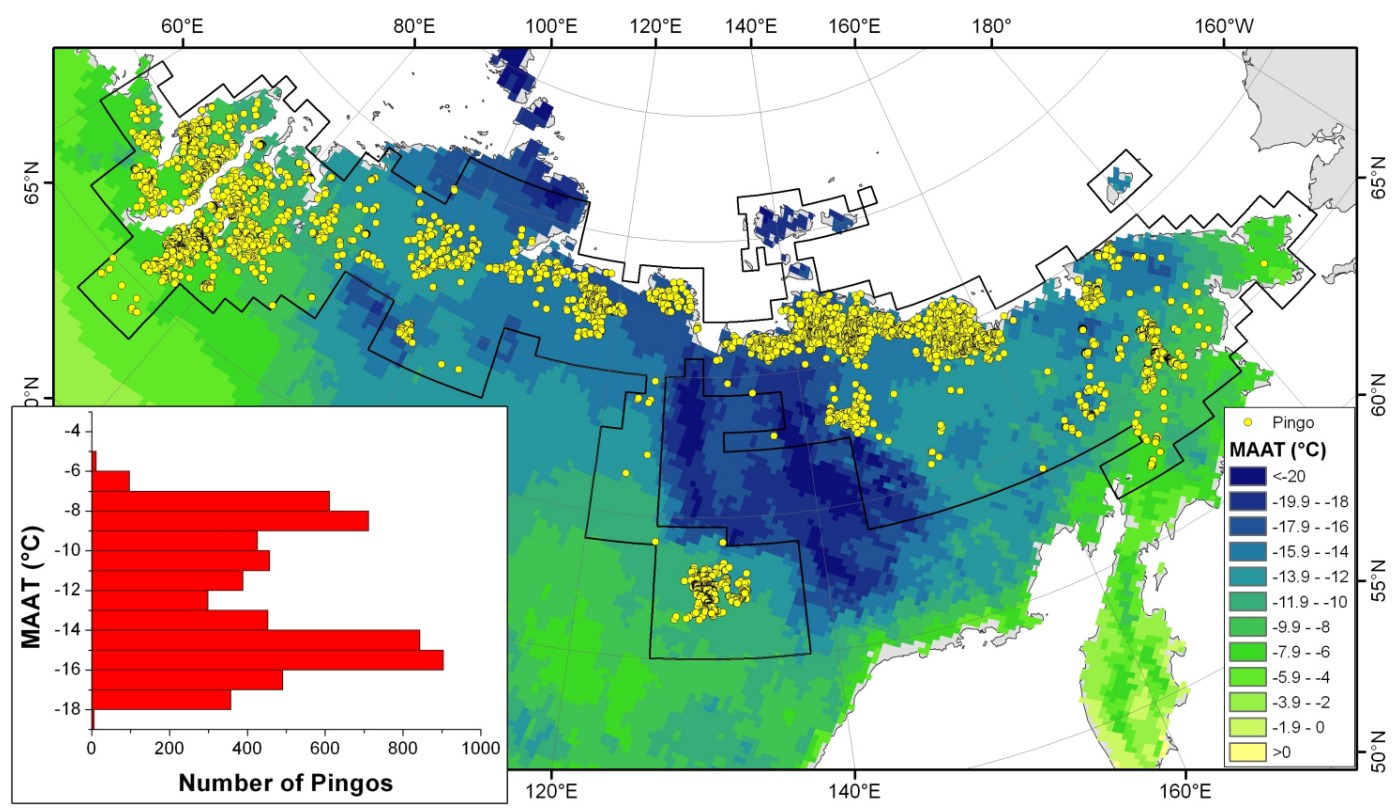

Fig. 11. Distribution of pingos by mean annual air temperature (MAAT) (based on Stolbovoy and McCallum, 2002).

Siberian lowlands. However, no regions with MAAT above $-5^{\circ} \mathrm{C}$ were included in the study region and it is thus unclear whether any pingos currently occur in North Asia above this MAAT.

Analysis of pingo distribution by MAP indicates a gradual decline in pingo numbers with increasing precipitation from 100 to $425 \mathrm{~mm}$. The northern coastal lowlands with very low precipitation rates have the highest numbers of pingos, which is especially pronounced in the Khatanga-Olenek lowlands, the Yana-Indigirka lowlands, and the Kolyma Lowlands. The spatial distribution of pingos versus MAAT and mean annual precipitation patterns reflects the occurrence of the majority of pingos in regions with a highly continental, cold and relatively arid climate.

\subsection{Distribution in relation to surface geology}

Pingo distribution in the study region is closely related to surface geology, i.e. lithology (Fig. 12). Major differences in surface geology in the study region, and thus also the suitability for pingo growth, are linked strongly to mountain vs. lowland landscape character, to past glaciations and permafrost history, and to dynamics of topography and drainage development during the Holocene. Only a very small number of pingos $(204 ; 3.4 \%)$ were identified in areas within the extent of the Last Glacial Maximum ice sheet and mountain glaciations in the region after Ehlers and Gibbard (2003). On the contrary, more than $50 \%$ of all pingo locations coincide with a region identified by Romanovskii (1993) as accumulation zone for Yedoma, a thick ice-rich permafrost deposit typical for non-glaciated regions (Schirrmeister et al., 2010), during the LGM. A large number of pingos (2525; 41.7\%) are found in lowland coastal plains in North East Siberia with limnic deposits, encompassing sequences of sandy to silty limnic and alluvial sediments. Most pingos in such regions were found in fully or partially drained thermokarst lake basins. These basins likely have refreezing taliks and permeable sandy sediment layers in the subsurface, and the majority of these pingos will be of the hydrostatic type typical for thermokarst lake basins (Mackay, 1978a). Large numbers of pingos $(754 ; 12.4 \%)$ are also related to alluvial deposits in large river deltas and fluvial valleys of the Lena, Yana, Indigirka, and Kolyma rivers. The presence of permeable sandy layers in these environmental settings allow for ground water movement towards a freezing front in refreezing taliks under e.g. abandoned river channels or floodplain terraces, allowing the formation of pingos (Fig. 6). Finally, morainic and fluvio-glacial sedimentary deposits in Northwest Siberia, the Taymyr Lowland and the Khatanga-Anabar lowlands provide medium to coarse-grained sandy lithologies allowing water migration and ice core growth in refreezing taliks (Fig. 12). 1558 pingos (25.7\%) are located in regions with such lithologies. A small number of pingos, potentially of hydraulic origin as described for other mountain regions (e.g., Hamilton and Obi, 1982), were identified in morainic and colluvial deposits of the Putorana Plateau region (51 pingos) and mountain regions in Chukotka (158 pingos).

\subsection{Distribution in relation to lakes and streams}

High pingo densities are often found in lake- and basinrich regions of the northern coastal lowlands. Comparison of our dataset of pingo distribution with lake area fraction (lake area per total land area) for a region derived from 


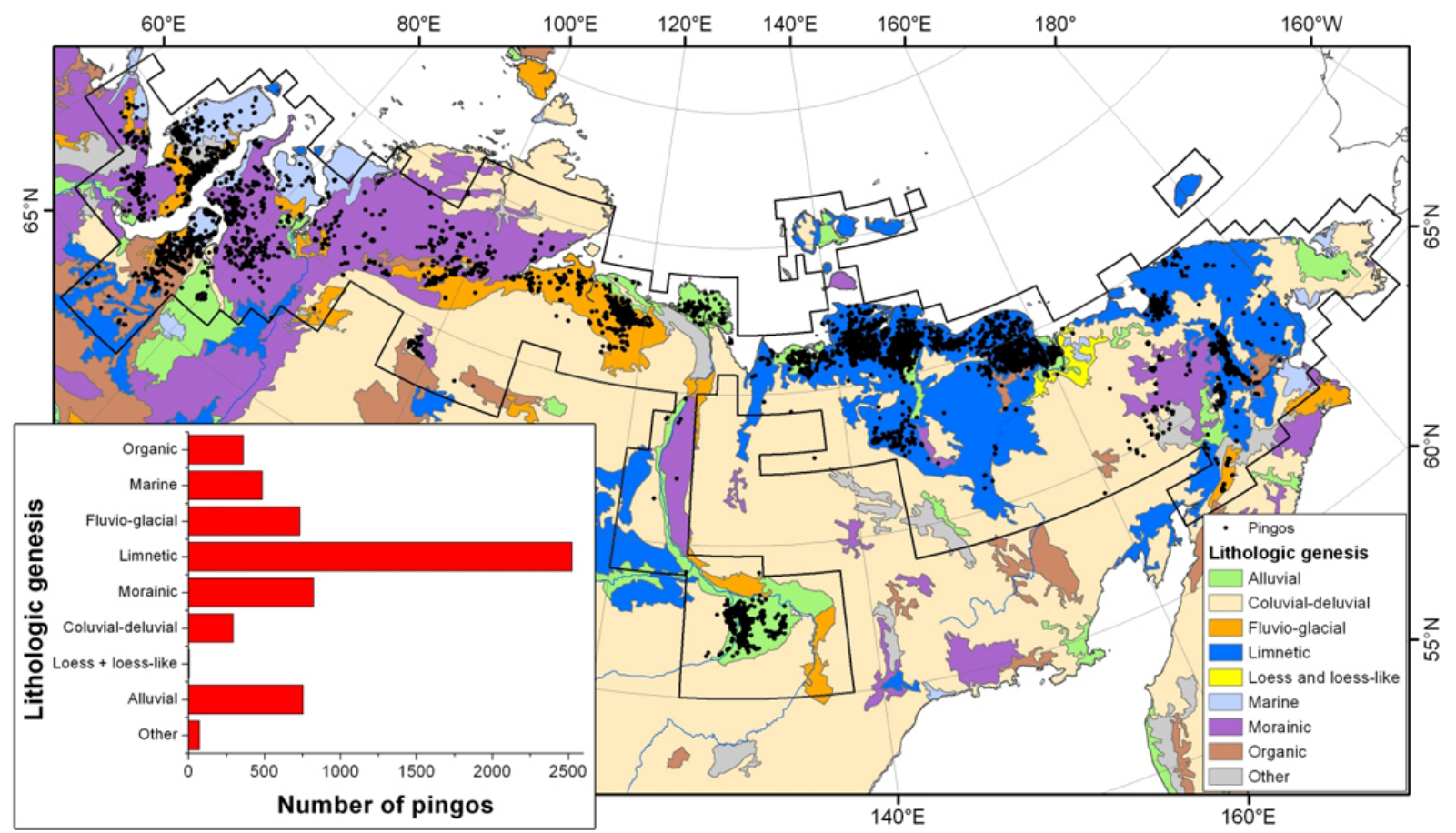

Fig. 12. Distribution of pingos by surface lithology (based on Stolbovoi et al., 2002).

the GLWD (Lehner and Döll, 2004) shows the tight coupling of thermokarst lake-rich regions in northern lowlands with the occurrence of pingos. Intense spatial dynamics of thermokarst lakes including formation, growth, shrinkage, and drainage of such lakes in these landscapes are indicated by a very high lake area fraction of up to $40-60 \%$ and the occurrence of a vast number of multiple generations of drained thermokarst lake basins (Fig. 6a). Talik formation and refreezing within these lake dynamics, in addition to sandy sediment layers permeable to ground water flow, play a key role for the formation of hydrostatic pingos in these lowlands. Detailed maps of pingo distribution in subregions of the study area (Fig. 6b) also reveal patterns that often align well with stream networks, indicating the connection of pingo growth to certain lithological and hydrological settings typical for river and stream corridors in permafrost regions.

\subsection{North Asian pingo distribution in a warming Arctic}

The current pingo distribution was analyzed in relation to scenarios of near-future, surface-permafrost distribution in northern Asia. Spatially distributed numerical permafrost models predict strong degradation of permafrost at the present day southern margins of its extent through 2100 (Romanovsky et al., 2008). According to Romanovsky et al. (2008), permafrost degradation will be especially strong in late Holocene permafrost of northwest, south central, and Pacific Siberia, with Late Pleistocene permafrost starting to thaw by the end of the century. Over the coming century, surface permafrost thawing is expressed by an increase in the active layer thickness (ALT) and the formation of taliks that could generate new hydrological conditions and enhance ground water runoff in the southern permafrost regions. Though the direct impact of an ALT increase on a pingo is depending also on the insulating sediment and soil overburden above the ice core, which can be substantial (Mackay, 1988), long-term substantial ALT increases can be seen as a general indicator for permafrost warming and starting degradation. These processes likely will affect pingos in these regions by (a) increasing MAGT to a level not sustainable for pingo growth and preservation in some regions (Mackay, 1988), (b) exposing the ice core of some pingos to above freezing temperatures followed by ice melting and pingo collapse and (c) by changing hydrological and pressure conditions in the talik necessary for pingo growth and preservation. The majority of pingos today occur in regions with ALTs between $0.5 \mathrm{~m}$ and $1.0 \mathrm{~m}$ (Fig. 13a). Exceptions are pingos in central Yakutia and West Siberia with ALTs up to $1.75 \mathrm{~m}$. Today, no pingos in our dataset occur in regions with ALTs more than $2.0 \mathrm{~m}$. However, by 2100 , several regions containing a total of 2073 pingos (34.2\%) will be affected by deepening of the ALT to more than $2.0 \mathrm{~m}$ (Fig. 13b). Regions most impacted are NW Siberia, including large parts of Yamal and Gydan peninsulas, parts of Central Siberia around Yakutsk, and the Pacific side of Chukotka. An increase in permafrost temperatures might shift some pingo populations out of their current range of stability, and projected increases 

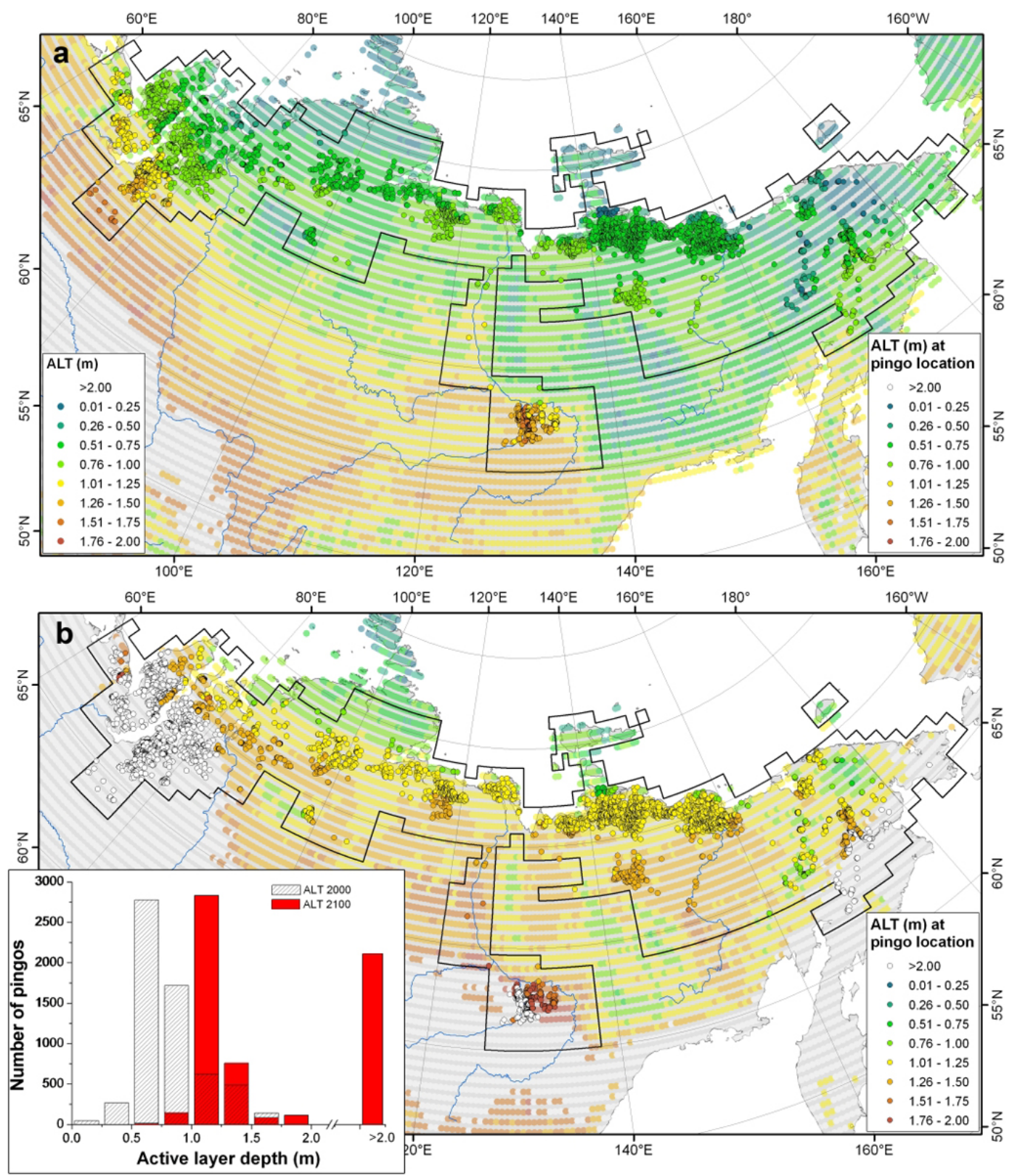

Fig. 13. Distribution of pingos by maximum active layer thickness (ALT) as modeled for the period (a) 1990-2000 and (b) 2090-2100 by Romanovsky et al. (2008). Histogram shows the shift of pingo populations from regions with ALT ranging from $0.25-1.5 \mathrm{~m}$ to ALT ranging from $0.75->2 \mathrm{~m}$ by the end of the 21 st century.

in ALT indicate that many regions with pingos will be affected from such a shift (Fig. 13). Pingos there could be increasingly prone to rapid collapse if the surface thawing reaches their ice core. The formation of pingo scars and new thermokarst ponds will likely be a result of this process. In other regions, ALT and permafrost temperatures will also increase, but is less likely to cause pingo collapse in this century.

\section{Discussion}

In general, our findings are in good agreement with previous research on environmental conditions required for pingo presence. With the majority of pingos in our dataset occuring in regions with permeable, medium to coarse grained sediments that are sometimes covered by finer grained lacustrine sediments we can confirm such unconsolidated sediment deposits as one important precondition for pingo formation (see also Mackay, 1978a; Gurney, 1998). This is in agreement with detailed findings by e.g. Carter and Galloway (1979) 
for the National Petroleum Reserve Alaska (NPRA), where about $97 \%$ of the 732 pingos mapped by are underlain by sandy unconsolidated deposits, and by Ferrians (1983) for the eastern Alaska Arctic Coastal Plain Similarly, where all ca. 300 pingos are underlain by sandy gravels and a thin cover of finer grained sediments.

A majority of pingos in our database is located in drained thermokarst basins in lake-rich lowlands massively reshaped by degradation of ice-rich Yedoma permafrost (Romanovskii, 1993; Schirrmeister et al., 2010) since the Late Glacial and early Holocene (Romanovskii et al., 2004; Grosse et al., 2007). Thermokarst lakes were major agents in reshaping these landscapes and resulted in deep thaw of permafrost beneath lakes in taliks. The dynamic cycling of thermokarst lakes involving formation, growth, and drainage or drying resulted in the presence of a considerably larger area covered by lake basins then by present-day thermokarst lakes in North Siberia (Grosse et al., 2006). We can use the pingos in our dataset as a paleoclimatic indicator. In the continuous permafrost zone of the study region, Holocene climatic conditions apparently were severe enough to allow refreezing of lake taliks after lake disappearence, which provided the environment necessary for hydrostatic pingo formation. The distribution and number of hydrostatic pingos has earlier been used to estimate lake drainage history beyond the remote sensing record (Marsh et al., 2009). Our dataset of pingo distribution, in combination with a relatively well-founded mechanistic understanding of their growth and collapse (Mackay, 1987, 1998) and the understanding that the age of pingos can be absolutely or relatively dated and largely are on the order of hundreds to few thousands of years old (Holmes et al., 1966; Mackay, 1978a; Walker et al., 1999), might thus be useful to access the long-term and broad-scale dynamics of thermokarst lake drainage in lowland regions in future studies. Interestingly, climate change might also result in the formation of new hydrostatic pingos in some regions due to increased occurence of thermokarst lake drainage or drying. Mackay (1998) describes the rapid growth of pingos after drainage of several lakes after 1935 on Tuktoyaktuk Peninsula. While some of the new pingos grew rapidly to $7.5 \mathrm{~m}$ height within 46 years, others collapsed again less than 12 years after initiation.

MAAT for pingo locations in our dataset largely (98\% of all sites) range from -18 to $-7^{\circ} \mathrm{C}$, which is in good agreement with previous assessments of pingos in North America: Mackay (1988) identified maximum MAAT for hydraulic pingos at -1 to $-3^{\circ} \mathrm{C}$ and for hydrostatic pingos at -4 to $-6^{\circ} \mathrm{C}$. Similarly, a MAGT range of -3 to $-11^{\circ} \mathrm{C}$ for $92 \%$ of pingos in our dataset agrees with maximum MAGT identified in previous studies $\left(<-2\right.$ to $\left.-4^{\circ} \mathrm{C}\right)$ (Mackay, 1988). Our comparison of pingo locations with projected end-ofcentury results from spatially distributed permafrost modeling (Romanovsky et al., 2008) has shown that large regions with pingos present will be affected by active layer increases by the year 2100 . Generally, direct impacts of small changes in active layer depth on pingo stability are unlikely due to the often up to several $\mathrm{m}$ thick overburden insulating the massive ice core (Mackay, 1988). However, if we consider the projected trend an active layer increase (Fig. 13) as indicator for general permafrost warming of also deeper horizons, pingos might become increasingly vulnerable to collapse. On a case-by-case basis, a warming-related collapse will therefore be difficult to predict in detail because of heterogeneity of pingo types and their internal structure. Variation in the type of ground-ice and the thickness of the overburden will strongly influence the response of an individual pingo to climate forcing. Whereby, pingo collapse will occur most commonly in those pingos where massive bodies exist near the surface, and pingo persistence will most likely occur for those pingos that have an overburden that exceeds the projected depth of thaw for the region. Further, owing to the conical shape of a pingo, the possibility of differential thaw on south facing and north facing slopes exist, further complicating the response of pingos to climate change. However, observed spatial patterns suggest that pingos do not occur below certain climatic and permafrost thresholds and thus are likely to disappear during changes crossing these thresholds in certain regions. A continued shift towards higher MAAT and MAGT in the study region as observed over the last decades (Romanovsky et al., 2010) could result in destablilization of permafrost and climate conditions required for pingo persistence and thus increased ice core melting and pingo collapse. Other complications in using the pingo dataset for tracing climate change impacts on permafrost may come from the possible collapse of pingos unrelated to climate change, which then could blur a potential regional degradation signal. Nonclimate related pingo collapse is part of the pingo lifecycle and has been observed in many regions (Mackay, 1987, 1998). Causes include coastal, fluvial, or lake erosion, or pingo growth-related processes such as oversteepening of slopes, crack formation, and summit, circumferential, or peripheral failure and collapse (Mackay, 1987). Whether a detailed spatial dataset of pingos could be used to trace the progression of projected permafrost degradation along climatic and permafrost gradients using remote sensing-based detection of pingo persistence or collapse should be explored in the future.

\subsection{Limitations of the pingo database}

In our initial effort to provide information on the presence and location of pingos over a vast region of the circumArctic, we have identified the occurrence of more than 6000 pingos in northern Asia. However, the presented dataset should be viewed as a minimum estimate of the distribution of pingos in this region, owing to the fact that some pingos remain unmapped in our study region as well as for the reported occurrence of pingos in adjacent areas of northern Asia. For example, pingo populations in Russia are also reported from the Pre-Baikal region, NW European Russia, and along the 
Okhotsk Sea coastal lowlands (e.g., Shumskii and Vtyurin, 1966). These other regions are not yet considered here, however, we believe that the main North Asian pingo provinces have been captured in the presented dataset thus far.

The presented data on pingo distribution are only as good as the topographic base maps used to derive the location information. At a topographic map scale of 1:200 000 some information from the original aerial photo mapping is certainly lost due to map generalization. Independent remote sensingbased data for the mapped pingos was assessed only for a very small fraction of the study region $\left(21600 \mathrm{~km}^{2}\right.$ out of $\left.3500000 \mathrm{~km}^{2} ; 0.6 \%\right)$. We here largely rely on the judgement of Russian aerial photo interpreters and map producers. Visual verification of small regions with high-resolution satellite data indicated that the general patterns of pingo distribution are well preserved in the 1:200 000 topographic maps.

In the Russian literature, pingo heights of $40-50 \mathrm{~m}$ or more for the studied region are frequently mentioned (Popov, 1963; Soloviev, 1973). Our source data, the topographic maps 1:200 000, cannot confirm this at this point, with the tallest pingo in the maps being labelled $37 \mathrm{~m}$ high and only 236 pingos labelled taller than $8 \mathrm{~m}$. However, height labels are provided only for about $51 \%$ of all mapped pingos, and possibly large numbers of pingos, even very tall ones, are still missing in these maps as indicated from initial remote sensing-based ground truth (see Sect. 3.2 on accuracy assessment using Terra ASTER imagery). We therefore have to consider the height analysis of the present dataset preliminary and not necessarily representative for the entire pingo population. Further analysis of larger scale maps, ground truth data, and remote sensing data will hopefully reduce this uncertainty in the pingo height distribution in the future.

Another general limitation of the database is the difficulty of distinguishing some small pingos from mineral palsas or lithalsas (Worsley et al., 1995; Gurney, 2001; Pissart, 2002) in remotely sensed data. Though the topographic maps label about $81 \%$ of the mapped features as pingos, there might be other types of perennial frost mounds included, depending on the interpretative capabilities of the aerial photo interpreters. In the future, this dataset could be used to analyze the specific local environmental settings at a site to better determine the likely genesis of a mapped perennial frost mound. The ultimate confirmation can only come from detailed field studies, which would be very helpful to refine the database and greatly decrease the level of uncertainty.

Ground truth for such a vast dataset is generally difficult to obtain and would require extensive field campaigns, geolocated, high-resolution aerial or satellite imagery, and highresolution elevation data such as from airborne Interferometric Synthetic Aperture Radar (IfSAR) or Light Detection and Ranging (LIDAR). In particular, existing historical and new field data from Russian permafrost and hydrogeological research should be used to further corroborate the dataset and enhance the GIS database, for example by including more morphometric characteristics of pingos. Finally, the thematic data used in this first order study to assess some of the environmental parameters relevant for pingos was coarse-scale and could be enhanced with finer-scale datasets that might become available in the future, which would allow enhanced spatial modelling of the pingo distribution. Our analysis of assessing the relation of pingo presence with ancillary datasets (elevation, bioclimatic zone, permafrost distribution, lake extent, etc.) covering such large regions undoubtedly limits interpretation of results at local scales, however regional differences are apparent and useful for interpretation of linkages between pingos and the character of the environment they occur in. For example, the elevation of the pingos derived with a $1 \mathrm{~km}$ DEM can only be used for a first order regional study, but is likely to contain errors on the local level because hydrostatic pingos occur in lowland landscapes with relief undulations below the DEM resolution, and hydraulic pingos often occur in valleys in mountainous regions for which the DEM resolution also does not apply very well.

Our initial presentation of a GIS database of pingo locations in northern Asia should be considered another step towards a circum-Arctic database of these prominent periglacial features. Our pingo database will eventually be made available through the world-wide web and will continually be updated to include further regions and by using satellite data and higher resolution topographic data as available for additional confirmation of pingo locations.

\subsection{Comparison with global pingo distribution}

Based on existing pingo counts in various regions of the Northern Hemisphere (Table 5), it is likely that there are about 11000 or more pingos on Earth. Thus, results from our compilation of a northern Asian pingo database roughly double previously published numbers. The majority of pingos are distributed across three main pingo provinces (Alaska, NW Canada, and North Asia), accounting for more than 10500 pingos (Table 5) or $>95 \%$ of the total population. Given the first results of our satellite data-based assessment for completeness of our dataset showing that many pingos are still missing in our map-derived dataset we can safely assume that this estimate is a minimum value.

Pingo densities reported from other studies are difficult to compare with results from this subcontinental scale study. Densities were frequently reported for small subsets of regions and pingo populations, usually as pingos per $\mathrm{km}^{2}$ of a certain landscape unit (Table 4). The highest densities for hydrostatic pingos so far were reported by Stager (1956) with up to eight pingos per $\mathrm{km}^{2}$ in the Mackenzie region, NW Canada, and for hydraulic pingos by Worsley and Gurney (1996) with eleven in less than one $\mathrm{km}^{2}$ on Traill Island, east Greenland. Commonly reported densities for Alaska sites are smaller than one pingo per $\mathrm{km}^{2}$ (e.g. Holmes et al., 1968; Walker et al., 1985). To account for spatial heterogeneity of pingo distribution we calculated pingo densities using a $10 \times 10 \mathrm{~km}$ kernel $\left(100 \mathrm{~km}^{2}\right)$ moving in $5 \mathrm{~km}$ steps. The 
Table 5. Selection of pingo regions and number of detected pingos.

\begin{tabular}{|c|c|c|}
\hline Region/subregion & Pingos & Source \\
\hline Canada, total & ca. 1500 & Mackay (1966) \\
\hline Richards Island, Tuktoyaktuk Peninsula, Canada & 1350 & Mackay (1966) \\
\hline Central Yukon Territory, Canada & 463 & Hughes (1969) \\
\hline Banks Island, Canada & $>100$ & French (1976) \\
\hline Alaska, total & $>1350$ & Ferrians $(1988)$ \\
\hline Alaska, total & 3166 & Yoshikawa (in Jorgenson et al., 2008) \\
\hline National Petroleum Reserve Alaska & 732 & Carter and Galloway (1979) \\
\hline Alaska Arctic coastal plain east of Colville River & $>300$ & Ferrians (1983) \\
\hline Prudhoe Bay region, Alaska & 102 & Walker et al. (1985) \\
\hline Brooks Range, Alaska & 70 & Hamilton and Obi (1982) \\
\hline Interior Alaska & ca. 300 & Holmes et al. $(1966,1968)$ \\
\hline Central east Greenland & $>70$ & Worsley and Gurney (1996) \\
\hline Svalbard & 80 & Yoshikawa and Harada (1995) \\
\hline Usa River Basin, Russia & 42 & Mazhitova and Oberman (2003) \\
\hline Northern Asia, Russia & 6059 & This study \\
\hline Northwest Siberian Lowland $\left(66.9-86.2^{\circ} \mathrm{E}\right)$ & ca. 1620 & This study \\
\hline Taymyr Lowland $\left(87.2-108.9^{\circ} \mathrm{E}\right)$ & ca. 260 & This study \\
\hline Khatanga-Anabar Lowland $\left(109.2-120.7^{\circ} \mathrm{E}\right)$ & ca. 360 & This study \\
\hline Lena River Delta $\left(123.5-129.4^{\circ} \mathrm{E}\right)$ & ca. 85 & This study \\
\hline Yana-Indigirka Lowland $\left(132.4-154.0^{\circ} \mathrm{E}\right)$ & ca. 1500 & This study \\
\hline Kolyma Lowland $\left(150.7-162.5^{\circ} \mathrm{E}\right)$ & ca. 700 & This study \\
\hline Central Yakutia $\left(126.0-133.6^{\circ} \mathrm{E}\right)$ & ca. 600 & This study \\
\hline Chukotka $\left(159.5^{\circ} \mathrm{E}-174.3^{\circ} \mathrm{W}\right)$ & ca. 735 & This study \\
\hline
\end{tabular}

results showed high variability of pingo densities between subregions and within subregions (Table 4; Fig. 5). However, the pingo densities in our study region are within previously reported ranges from other regions. The possibility of very high pingo densities for some sites in Siberia, similar to that of Stager (1956) or Worsley and Gurney (1996), cannot be ruled out since in at least one occasion a labelled pingo field was simply identified as one pingo in the topographic maps, which subsequently was mapped as a single pingo in our dataset, and because of pingos still missing in the database (see also Table 1).

\subsection{Database development for periglacial landforms}

Through the development of sophisticated GIS platforms the utility of compiling and comparing spatial information on numerous variables is possible. Our pingo database for northern Asia can be updated to include data derived from higher-resolution imagery as well as inclusion of other regions of Siberia and the circum-Arctic. Not only will detailed GIS pingo databases such as the one presented here prove useful for making comparison between circum-Arctic regions that vary by climate, vegetation, and history but it may also prove useful for characterizing other landscape patterns and phenomenon associated with hydrology in permafrost regions, such as thermokarst lake drainage history or permafrost and talik character. We believe that similar to our initial compilation of information on the location of pingos across much of northern Asia, the development of large regional GIS databases and maps for other terrestrial periglacial landforms such as ice wedge polygonal networks, other frost mound types, water-tracks, thermo-erosional valleys, thaw slumps, etc. would be beneficial for better understanding of broad-scale permafrost distribution and its character. Remote sensing will play a major role in such efforts.

\section{Conclusions}

We present a high-resolution GIS dataset of pingos for a large region in North Asia that allows first order spatial analysis of environmental parameters critical for characterization of pingo distribution. Confirming previous studies, surface lithology, hydrology, and the surface and subsurface thermal regime were found to be key factors for the presence of pingos. A clear association with limnic and a range of coarse to medium-grained lithologies and a high sediment thickness highlights the need for permeable layers for pingo growth. The majority of pingos are located in thermokarst-dominated lowlands of the continuous permafrost zone and likely formed through talik refreezing as hydrostatic pingos, typical for drained/draining thermokarst lake basins in settings with very low mean annual air temperatures. Detailed GIS pingo databases may therefore prove useful for characterizing long-term temporal 
and spatial thermokarst lake dynamics, i.e., regarding lake area loss due to drainage or drying. We believe that this dataset represents a step towards an integrated pan-Arctic geospatial database of frost mounds useful to analyze past and modern permafrost and climate conditions as related to permafrost formation and stability.

Based on our dataset and data available from other pingo regions, we estimate that there are more than 11000 pingos on Earth, which roughly doubles previously published counts. Near-future reduction in permafrost extent will likely impact pingo distribution in North Asia, including a reduction in pingo numbers due to thawing and collapse, and formation of pingo scars and thermokarst ponds. The present dataset could potentially be used as a base for an extensive monitoring of pingos as indicators of permafrost degradation in discontinuous permafrost regions and along the present southern boundary of continuous permafrost.

Acknowledgements. This work was partially supported by NASA NNX08AJ37G. We thank V. Romanovsky and S. Marchenko (University of Alaska Fairbanks) for providing maps of future permafrost distribution and maximum active layer depths for northern Eurasia and discussions about impacts of permafrost degradation on pingos. We also thank L. Schirrmeister and Ch. Siegert (AWI Potsdam) as well as J. Galloway and F. Urban (USGS) for friendly reviews of an early version of the manuscript and very constructive comments. N. Ross and an anonymous reviewer provided helpful reviews that further enhanced the paper.

Edited by: T. Zhang

\section{References}

Andreev, V. N.: Gidrolakkolity (bulgunnyakhi) v zapadnosibirskykh tundrakh [Hydrolakkoliths (Bulgunnyakhs) in the west Siberian tundra], Isv. Russk. Geogr. Ob-va., 68(2), 1936. (in Russian)

Bobov, N. G.: Pingo formations under modern conditions in the watershed between the Lena and Vilyui Rivers, Geographical Series, Academy of the Sciences of the USSR, 5, 64-68, 1960. (in Russian)

Brown, R. J. E. and Pewe, T. L.: Distribution of permafrost in North America and its relationship to the environment - A review 1963-1973, in: The North American Contribution to the Second International Conference of Permafrost, Yakutsk, U.S.S.R., 71100, 13-28 July 1973.

Brown, J., Ferrians, O. J., Heginbottom, J. A., and Melnikov, E.: Circum-Arctic Map of Permafrost and Ground-Ice Conditions, in: Circumpolar Active-Layer Permafrost System, Version 2.0, edited by: Parsons, M. and Zhang, T., International Permafrost Association Standing Committee on Data Information and Communication (comp.), 2003, National Snow and Ice Data Center/World Data Center for Glaciology, Boulder, CO, CD-ROM, 1998.

Carter, L. D. and Galloway, J. P.: Arctic Coastal Plain pingos in National Petroleum Reserve in Alaska, in: The United States Geological Survey in Alaska - Accomplishments during 1978, edited by: Johnson, K. M. and Williams, J. K., US Geological Survey Circular, 804-B, 33-35, 1979.

Craig, B. G.: Pingo in the Thelon Valley, Northwest Territories; Radio-carbon age and historical significance of the contained organic material, Geol. Soc. Am. Bull., 70, 509-510, 1959.

Ehlers, J. and Gibbard, P. L.: Extent and chronology of glaciations, Quaternary Sci. Rev., 22, 1561-1568, 2003.

Ershov, E. D., Kondrateeva, K. A., Loginov, V. F., and Sytchev, I. K.: Geocyological map of the Soviet Union [Geokryologitcheskaya karta SSSR], Scale 1:2500 000, Moscow State University, 1991.

Esper Angillieri, M. Y.: A preliminary inventory of rock glaciers at $30^{\circ} \mathrm{S}$ latitude, Cordillera Frontal of San Juan, Argentina, Quatern. Int., 195, 151-157, 2009.

Evseev, V. P.: Pingos of segregated ice in the northeast of the European part of the U.S.S.R in Western Siberia, Problemy Kriolitologii, 5, 95-159, 1976 (in Russian).

Ferrians Jr., O. J.: Pingos on the Arctic Coastal Plain, northeastern Alaska, in: Fourth International Conference on Permafrost, Fairbanks, Alaska, University of Alaska, 105-106, 18-22 July 1983.

Ferrians Jr., O. J.: Pingos in Alaska: A review, in: Fifth International Conference on Permafrost, Norway, 734-739, 1988.

Flemal, R. C.: Pingos and pingo scars: Their characteristics, distribution, and utility in reconstructing former permafrost environments, Quaternary Res., 6, 37-53, 1976.

French, H. M.: Pingo investigations, Banks Island, District of Franklin, Geological Survey of Canada, 76-1A, 235-238, 1976.

French, H. M.: Past and present permafrost as an indicator of climate change, Polar Res., 18, 269-274, 1999.

Galloway, J. P. and Carter, L. D.: Preliminary map of pingos in National Petroleum Reserve in Alaska, U.S. Geological Survey Open-File Report 78-795, 1 sheet, scale 1:500,000, 1978.

GLOBE Task Team: The Global Land One-kilometer Base Elevation (GLOBE) Digital Elevation Model, Version 1.0, National Oceanic and Atmospheric Administration, National Geophysical Data Center, Boulder, Colorado, USA, 1999.

Grave, N. A.: On the archaeological dating of hydrolaccoliths on the Chukotka Peninsula, Dokl. Akad. Nauk, 106, 706-707, 1956 (in Russian).

Grosse, G., Schirrmeister, L., and Malthus, T. J.: Application of Landsat-7 satellite data and a DEM for the quantification of thermokarst-affected terrain types in the periglacial Lena-Anabar coastal lowland, Polar Res., 25, 51-67, 2006.

Grosse, G., Schirrmeister, L., Siegert, C., Kunitsky, V. V., Slagoda, E. A., Andreev, A. A., and Dereviagyn, A. Y.: Geological and geomorphological evolution of a sedimentary periglacial landscape in Northeast Siberia during the Late Quaternary, Geomorphology, 86, 25-51, 2007.

Gurney, S. D.: Aspects of the genesis and geomorphology of pingos: perennial permafrost mounds, Prog. Phys. Geog., 22, 307324, 1998.

Gurney, S. D.: Aspects of the genesis, geomorphology and terminology of palsas: perennial cryogenic mounds, Prog. Phys. Geog., 25, 249-260, 2001.

Hamilton, T. D. and Obi, C. M.: Pingos in the Brooks Range, Northern Alaska, USA, Arctic Alpine Res., 14, 13-20, 1982.

Harris, S. A.: Identification of permafrost zones using selected permafrost landforms, in: Proceedings of the fourth Canadian Per- 
mafrost Conference, 1982, 49-58, 1982.

Hinkel, K. M., Frohn, R. C., Nelson, F. E., Eisner, W. R., and Beck, R. A.: Morphometric and spatial analysis of thaw lakes and drained thaw lake basins in the Western Arctic Coastal Plain, Alaska, Permafrost Periglac., 16, 327-341, 2005.

Hinzman, L. D., Bettez, N. D., Bolton, W. R., Chapin, F. S., Dyurgerov, M. B., Fastie, C. L., Griffith, B., Hollister, R. D., Hope, A., Huntington, H. P., Jensen, A. M., Jia, G. J., Jorgenson, T., Kane, D. L., Klein, D. R., Kofinas, G., Lynch, A. H., Lloyd, A. H., McGuire, A. D., Nelson, F. E., Oechel, W. C., Osterkamp, T. E., Racine, C. H., Romanovsky, V. E., Stone, R. S., Stow, D. A., Sturm, M., Tweedie, C. E., Vourlitis, G. L., Walker, M. D., Walker, D. A., Webber, P. J., Welker, J. M., Winker, K. S., and Yoshikawa, K.: Evidence and Implications of Recent Climate Change in Northern Alaska and Other Arctic Regions, Climatic Change, 72, 251-298, 2005.

Holmes, G. H., Foster, H. L., and Hopkins, D. M.: Distribution and age of pingos of Interior Alaska, in: Proceedings Permafrost International Conference, N.R.C. Publication 1287, Washington, D.C., National Academy of Sciences, 88-93, 1966.

Holmes, G. W., Hopkins, D. M., and Foster, H.: Pingos in central Alaska, US Geological Survey Bulletin, 1241-H, Washington, H1-H40, 44 pages, 1968.

Hughes, O. L.: Distribution of open system pingos in central Yukon Territory with respect to glacial limits, Geological Survey of Canada, Paper 69-34, 1969.

Huijzer, B. and Vandenberghe, J.: Climatic reconstruction of the Weichselian Pleniglacial in northwestern and Central Europe, J. Quaternary Sci., 13, 391-417, 1998.

Isarin, R. F. B.: Permafrost distribution and temperatures in Europe during the Younger Dryas, Permafrost Periglac., 8, 313333, 1997.

Jin, H. J., Chang, X. L., and Wang, S. L.: Evolution of permafrost on the Qinghai-Xizang (Tibet) Plateau since the end of the late Pleistocene, J. Geophys. Res., 112, F02S09, doi:10.1029/2006JF000521, 2007.

Jorgenson, T., Yoshikawa, K., Kanevskiy, M., Shur, Y., Romanovsky, V., Marchenko, S., Grosse, G., Brown, J., and Jones, B.: Permafrost characteristics of Alaska, in: Proceedings of the Ninth International Conference on Permafrost, Fairbanks, Alaska, 29 June-3 July 2008.

Kotlyakov, V. and Khromova, T.: Permafrost, Snow and Ice, in: Land Resources of Russia, Digital Media, edited by: Stolbovoi, V. and McCallum, I., International Institute for Applied Systems Analysis and the Russian Academy of Science, Laxenburg, Austria, 2002.

Lagerbäck, R. and Rohde, L.: Pingos in northernmost Sweden, Geogr. Ann. A, 67(3-4), 239-245, 1985.

Leffingwell, E. d. K.: The Canning River region, northern Alaska, in: United States Geological Survey Professional Paper 109, USGS, Washington, DC, 251, 1919.

Lehner, B. and Döll, P.: Development and validation of a global database of lakes, reservoirs and wetlands, J. Hydrol., 296, 1-22, 2004.

Lomborinchen, R.: Frost heaving and related landforms, Mongolia, Permafrost Periglac., 11, 85-90, 2000.

Luoto, M. and Seppälä, M.: Modelling the distribution of palsas in Finnish Lapland with logistic regression and GIS, Permafrost Periglac., 13, 17-28, 2002.
Mackay, J. R.: Pingos of the Pleistocene Mackenzie Delta area, Geographical Bulletin, 18, 21-63, 1962.

Mackay, J. R.: Pingos in Canada, in: First International Conference on Permafrost, Lafayette, Indiana, 1963, National Academy of Science - National Research Council, Washington, D.C., Publication 1287, 108-113, 1966.

Mackay, J. R.: The world of underground ice, Ann. Assoc. Am. Geogr., 62, 1-22, 1972.

Mackay, J. R.: Age of Ibyuk Pingo, Tuktoyaktuk Peninsula, District of Mackenzie, Geological Survey of Canada, 76(1B), 59-60, 1976.

Mackay, J. R.: Contemporary pingos; a discussion, Biuletyn Peryglacjalny, 27, 133-154, 1978a.

Mackay, J. R.: Sub-pingo water lenses, Tuktoyaktuk Peninsula, Northwest Territories, Can. J. Earth Sci., 15, 1219-1227, 1978 b.

Mackay, J. R.: Pingos of the Tuktoyaktuk Peninsula area, Northwest Territories, Geogr. Phys. Quatern., 33, 3-61, 1979.

Mackay, J. R.: Growth of Ibyuk Pingo, western Arctic coast, Canada, and some implications for environmental reconstructions, Quaternary Res., 26, 68-80, 1986.

Mackay, J. R.: Some mechanical aspects of pingo growth and failure, western Arctic coast, Canada, Can. J. Earth Sci., 24, 11081119, 1987.

Mackay, J. R.: Pingo collapse and paleoclimatic reconstruction, Can. J. Earth Sci., 25, 495-511, 1988.

Mackay, J. R.: Pingo growth and collapse, Tuktoyaktuk Peninsula Area, Western Arctic Coast, Canada: A long-term field study, Geogr. Phys. Quatern., 52, 271-323, 1998.

Marsh, P., Russell, M., Pohl, S., Haywood, H., and Onclin, C.: Changes in thaw lake drainage in the Western Canadian Arctic from 1950 to 2000, Hydrol. Process., 23, 145-158, 2009.

Matsuoka, N.: Solifluction rates, processes and landforms: a global review, Earth-Sci. Rev., 55, 107-134, 2001.

Mazhitova, G. and Oberman, N.: Permafrost of the Usa River Basin, National Snow and Ice Data Center/World Data Center for Glaciology, Boulder, CO, Digital Media, 2003.

Mitchell, G. F.: Fossil pingos in the south of Ireland, Nature, 230, 43-44, 1971.

Müller, F.: Observations on pingos - Detailed studies in East Greenland and the Canadian Arctic [Beobachtungen über Pingos, Detailuntersuchungen in Ostgrönland und in der Kanadischen Arktis], Meddelelser om Grønland, 153(3), 127 pp., 1959.

Nelson, F. E.: Cryoplanation terrace orientation in Alaska, Geogr. Ann. A, 80, 135-151, 1998.

New, M., Hulme, M., and Jones, P. D.: Representing twentieth century space-time climate variability, part 1: development of a 1961-90 mean monthly terrestrial climatology, J. Climate, 12, 829-856, 1999.

Pissart, A.: Palsas, lithalsas and remnants of these periglacial mounds, A progress report, Prog. Phys. Geog., 26, 605-621, 2002.

Popov, A. I., Kachurin, S. P., and Grave, N. A.: Features of the development of frozen geomorphology in northern Eurasia, in: First International Conference on Permafrost, Lafayette, Indiana, 1963, National Academy of Science, National Research Council, Washington, D.C., Publication 1287, 181-185, 1963.

Porsild, A. E.: Earth mounds in unglaciated arctic northwestern America, Geogr. Rev., 28(1), 46-58, 1938.

Romanovskii, N. N.: Fundamentals of cryogenesis of lithosphere, 
Moscow University Press, Moscow, Russia, 336, 1993 (in Russian).

Romanovskii, N. N., Hubberten, H.-W., Gavrilov, A. V., Tumskoy, V. E., and Kholodov, A. L.: Permafrost of the east Siberian Arctic shelf and coastal lowlands, Quaternary Sci. Rev., 23, 1359-1369, 2004.

Romanovsky, V. E., Kholodov, A. L., Marchenko, S. S., Oberman, N. G., Drozdov, D. S., Malkova, G. V., Moskalenko, N. G., Vasiliev, A. A., Sergeev, D. O., and Zheleznyak, M. N.: Thermal State and Fate of Permafrost in Russia: First Results of IPY, in: Proceedings of the Ninth International Conference on Permafrost, Fairbanks, Alaska, 1511-1518, 29 June-3 July 2008.

Romanovsky, V. E., Drozdov, D. S., Oberman, N. G., Malkova, G. V., Kholodov, A. L., Marchenko, S. S., Moskalenko, N. G., Sergeev, D. O., Ukraintseva, N. G., Abramov, A. A., Gilichinsky, D. A., and Vasiliev, A. A.: Thermal state of permafrost in Russia, Permafrost Periglac., 21, 136-155, 2010.

Ross, N., Harris, C., Christiansen, H. H., and Brabham, P. J.: Ground penetrating radar investigation of open system pingos, Adventdalen, Svalbard, Norweg. J. Geograph., 59, 129-138, 2005.

Ross, N., Brabham, P. J., Harris, C., and Christiansen, H. H.: Internal structure of open system pingos, Adventdalen, Svalbard: The use of resistivity tomography to assess groundice conditions, J. Environ. Eng. Geophy., 12, 113-126, doi:10.2113/JEEG12.1.113, 2007.

Sazonova, T. S. and Romanovsky, V. E.: A model for regionalscale estimation of temporal and spatial variability of active layer thickness and mean annual ground temperatures, Permafrost Periglac., 14, 125-139, 2003.

Schirrmeister, L., Kunitsky, V., Grosse, G., Wetterich, S., Meyer, H., Schwamborn, G., Babiy, O., Derevyagin, A., and Siegert, C.: Sedimentary characteristics and origin of the Late Pleistocene Ice Complex on North-East Siberian Arctic coastal lowlands and islands - a review, Quatern. Int., doi:10.1016/j.quaint.2010.04.004, in press, 2010.

Shumskii, P. A. and Vtyurin, B. I.: Underground ice, in: First International Conference on Permafrost, Lafayette, Indiana, 1963, National Academy of Science, National Research Council, Washington, D.C., Publication 1287, 108-113, 1966.

Soloviev, P. A.: Bulgunnyakhi Zentralnoi Yakutii [Bulgunnyakhs of Central Yakutia], in: Investigation of permafrost in the Yakutian ASSR [Issledovanie vechnoi merzloty v YaASSR], Moscow, Publishing House Acad. Science SSSR, 226-258, 1952 (in Russian).

Soloviev, P. A.: Thermokarst phenomena and landforms due to frostheaving in central Yakutia, Biuletyn Peryglacjalny, 23, 135155, 1973.

Stager, J. K.: Progress report on the analysis of the characteristics and distribution of pingos east of the Mackenzie Delta, Can. Geogr., 7, 13-20, 1956.

Stolbovoi, V. and McCallum, I.: Land Resources of Russia, Digital Media, International Institute for Applied Systems Analysis and the Russian Academy of Science, Laxenburg, Austria, 2002.

Stolbovoi, V., Fischer, G., Ovechkin, V. S., and Rozhkova, S.: Vegetation, The IIASA-LUC Project Georeferenced Database of the Former U.S.S.R., Vol. 4: Vegetation, Interim Report IR-98, in: Land Resources of Russia, edited by: Stolbovoi, V. and McCallum, I., Digital Media, International Institute for Applied Sys- tems Analysis and the Russian Academy of Science, Laxenburg, Austria, 2002, 1998.

Stolbovoi, V., Savin, I., Sheremet, B., and Kolesnikova, L.: Soil Reference Profiles, in: Land Resources of Russia, edited by: Stolbovoi, V. and McCallum, I., Digital Media, International Institute for Applied Systems Analysis and the Russian Academy of Science, Laxenburg, Austria, 2002, 2002.

Tolstikhin, N. I.: Podzemnye vody Zabaikalya i ikh gidrolakkolity [Groundwater in Zabaikalia and Hydrolakkoliths], Tr. Kom. lo vetshn. Merslote, 1932 (in Russian).

Vandenberghe, J. and Pissart, A.: Permafrost changes in Europe during the last glacial, Permafrost Periglac., 4, 121-135, 1993.

Vasilchuk, Y. K. and Budantseva, N. A.: Radiouglerodnoe opredelenye vosrasta bulgunnyakha na mestoroshdenii peszovoe $\mathrm{v}$ severnoi zhasti Sapadnoi Sibiri [Radiocarbon dating of the pingo in the Pestsovoye gas field in the North of West Siberia], Eng. Geol., 14-21 July 2010 (in Russian).

Walker, D. A., Walker, M. D., Everett, K. R., and Webber, P. J.: Pingos of the Prudhoe Bay Region, Alaska, Arctic Alpine Res., 17, 321-336, 1985.

Walker, D. A., Epstein, H. E., Romanovsky, V. E., Ping, C. L., Michaelson, G. J., Daanen, R. P., Shur, Y., Peterson, R. A., Krantz, W. B., Raynolds, M. K., Gould, W. A., Gonzalez, G., Nicolsky, D. J., Vonlanthen, C. M., Kade, A. N., Kuss, P., Kelley, A. M., Munger, C. A., Tarnocai, C. T., Matveyeva, N. V., and Daniëls, F. J. A.: Arctic patterned-ground ecosystems: A synthesis of field studies and models along a North American Arctic Transect, J. Geophys. Res., 113, G03S01, doi:10.1029/2007JG000504, 2008.

Walker, M. D., Everett, K. R., Walker, D. A., and Birkeland, P. W.: Soil Development as an Indicator of Relative Pingo Age, Northern Alaska, USA, Arctic Alpine Res., 28, 352-362, 1996.

Walter, K. M., Edwards, M. E., Grosse, G., Zimov, S. A., and Chapin III, F. S.: Thermokarst lakes as a source of atmospheric CH4 during the last deglaciation, Science, 318, 633-636, doi:10.1126/science.1142924, 2007.

Wang, B. and French, H. M.: Permafrost on the Tibet Plateau, China, Quaternary Sci. Rev., 14, 255-274, 1995.

Washburn, A. L.: Permafrost features as evidence of climatic change, Earth-Sci. Rev., 15, 327-402, 1980.

Worsley, P. and Gurney, S. D.: Geomorphology and hydrogeological significance of the Holocene pingos in the Karup Valley area, Traill Island, northern east Greenland, J. Quaternary Sci., 11, 249-262, 1996.

Worsley, P., Gurney, S. D., and Collins, P. E. F.: Late holocene "mineral palsas" and associated vegetation patterns: A case study from Lac Hendry, Northern Quebec, Canada and significance for European Pleistocene Thermokarst, Quaternary Sci. Rev., 14, 179-192, 1995.

Yoshikawa, K.: Age of growth of two pingos, Sarqaq Dalen, West Central Greenland, Permafrost Periglac., 2, 245-252, 1991.

Yoshikawa, K. and Harada, K.: Observations on nearshore pingo growth, Adventdalen, Spitsbergen, Permafrost Periglac., 6, 361372, 1995.

Yoshikawa, K., Leuschen, C., Ikeda, A., Harada, K., Gogineni, P., Hoekstra, P., Hinzman, L., Sawada, Y., and Matsuoka, N.: Comparison of geophysical investigations for detection of massive ground ice (pingo ice), J. Geophys. Res., 111, EO6S19, doi:10.1029/2005JE002573, 2006. 